$$
\text { تبيين يديدارشناسانهُ اصول برنامهٔ درسى ((تجربه تدريس)(كارورزى) در }
$$

\title{
Phenomenological Explanation of Curriculum Principles of the Teaching Experience (Internship) in Farhangian University
}

A. Davoodi, N. Keshtiaray (Ph. D),

A. Yusefi (Ph. D)

Abstract: The purpose of this study was to define the curriculum principles of Teaching Experience based on the lived experiences of the successful teachers. In this study, a qualitative method with a phenomenological approach was used. The participants were 9 teachers and professors who were selected purposefully. Data were collected by using in-depth interview and analyzed by thematic coding. Among the findings, 358 conceptual codes were extracted. They were classified as eight main categories including: caring and sympathy, dynamism, tact of teaching, introspection, mutual interaction, creating reflective situations, cultural-artistic understanding, practical insight and 35 subcomponents. Findings indicated that following these principles results in the improvement of moral behavior and behavior stability in learners and can guarantee the influence of the learningteaching process.

Key Words: principles of curriculum, teaching experience, internship, teachers

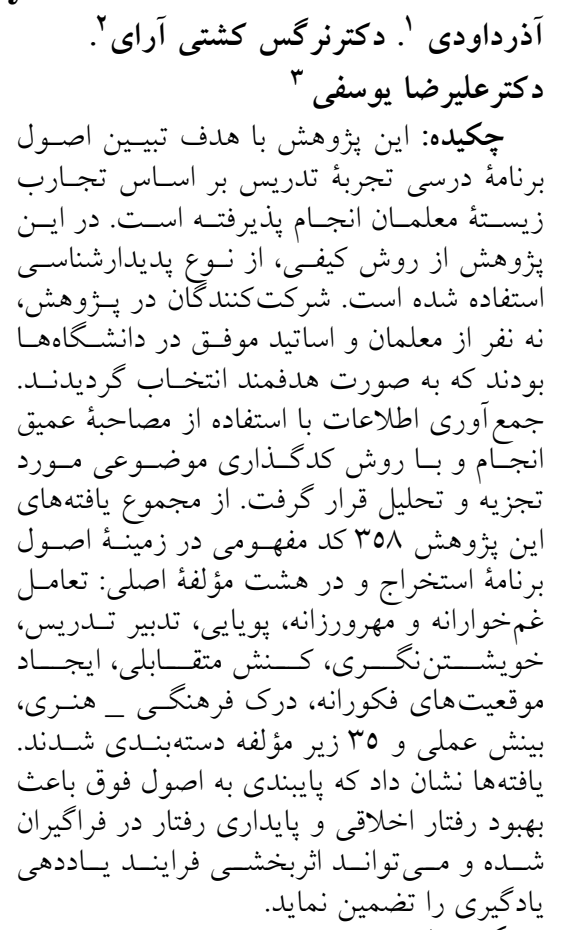

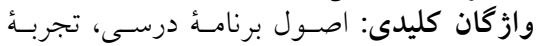

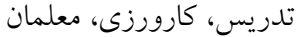

\footnotetext{
1. دانشجوى دكترى برنامه درسى، واحد اصفهان (خوراسگان)، دانشخاه ازاد اسلامى، اصفهان،

a_davoodi_36@yahoo.com ايران.

r. استاديار گروه برنامه درسى، واحد اصفهان (خوراسگان)، دانشگاه ازاد اسلامى، اصفهان، ايران.

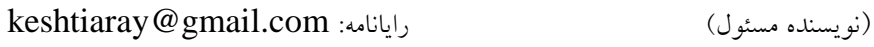

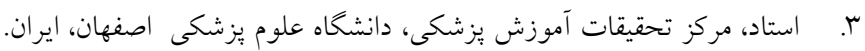

رايانامه:

ع. تاريخ دريافت مقاله: 1// 1/
} 


\section{مقدمه}

بشر امروز به خوبى دريافته است كه تحول در آموزش و يرورش بيش نيازى براى

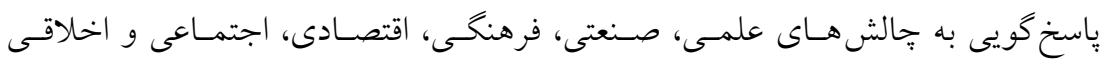

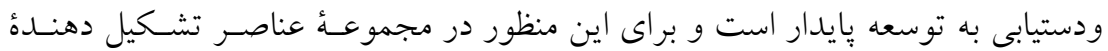

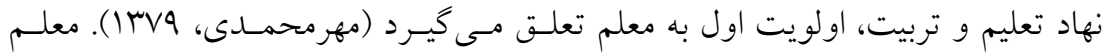

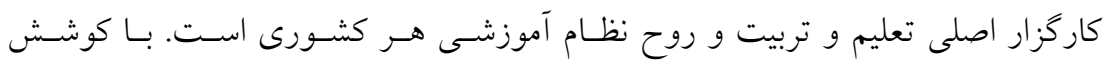

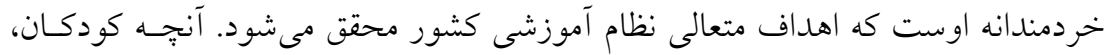

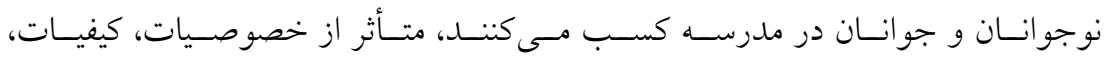

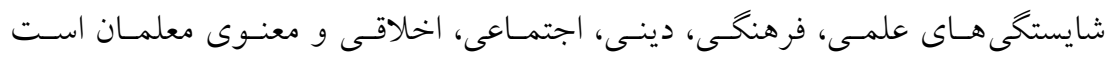

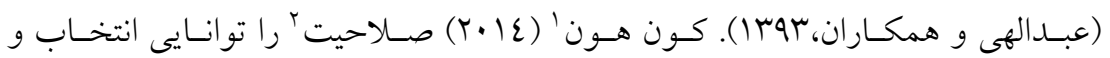

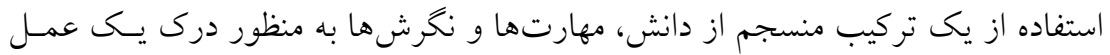

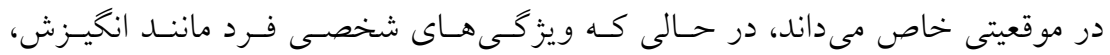

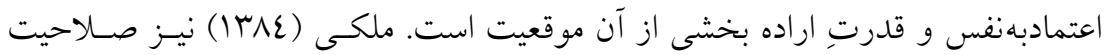

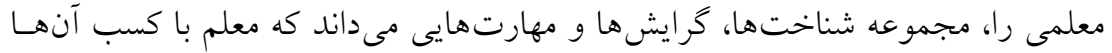

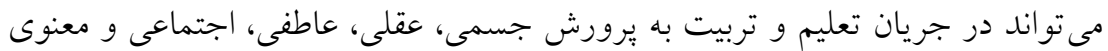

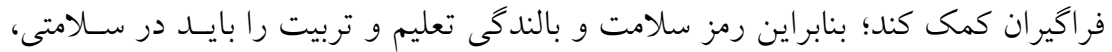

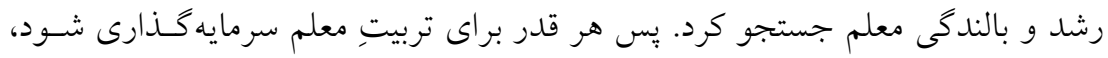

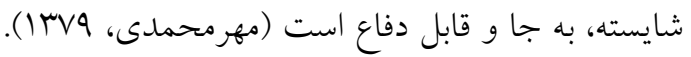

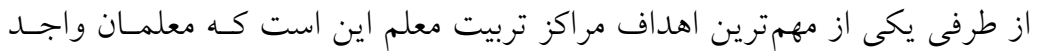

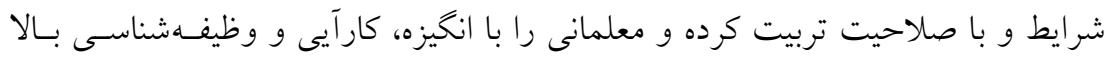

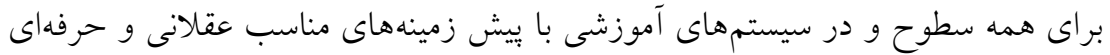

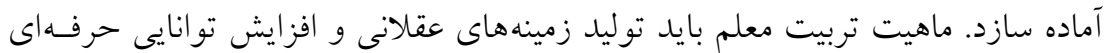

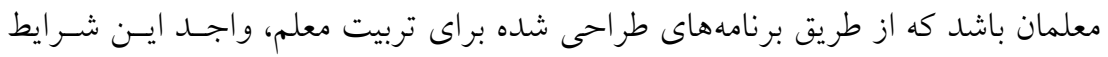

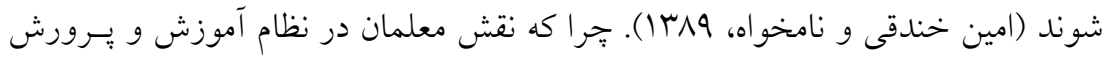

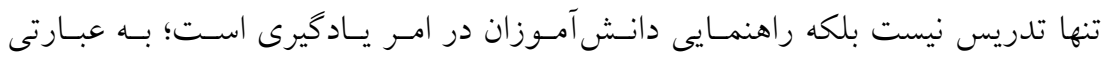

1 Kouwenhoven

2 competency 
تبيين يديدارشناسانهُ اصول برنامهُ درسى ("تجربه تدريس)...

يادگيرنده بايد بياموزد كه جّكونه ياد بحيرد. عامل تحقق اين امر معلم است و معلم خود

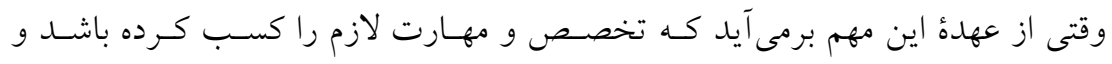

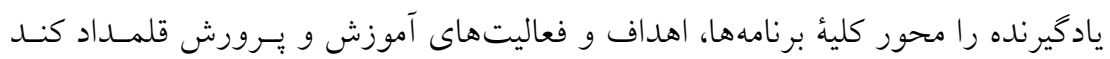

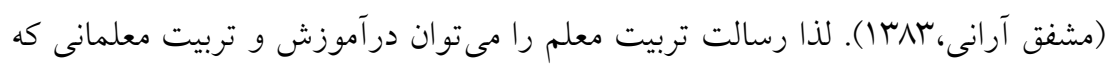

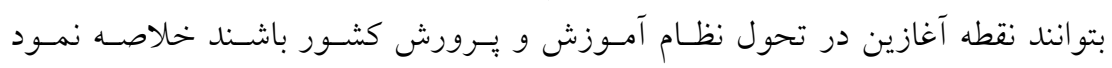

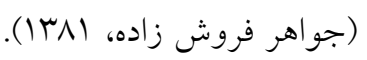

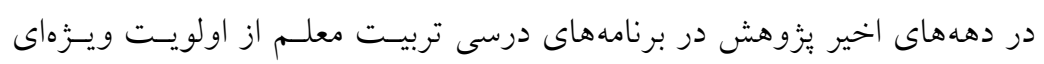

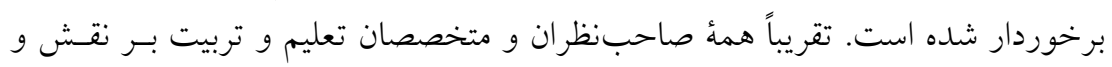

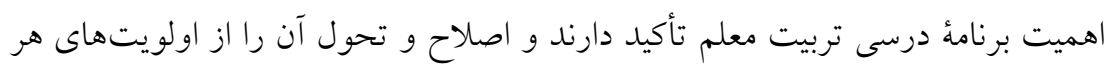

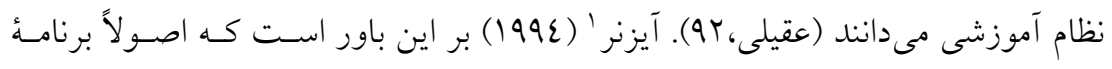

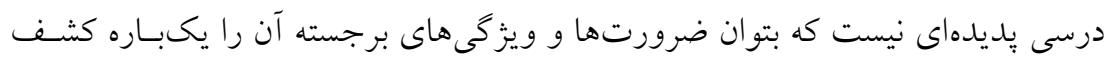

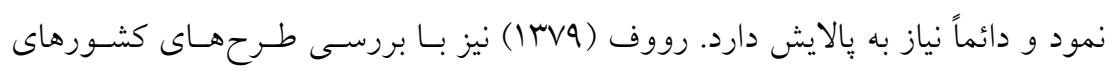

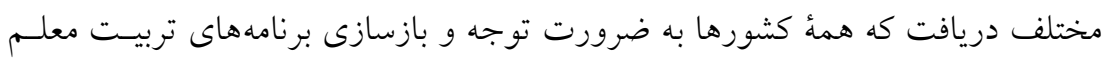

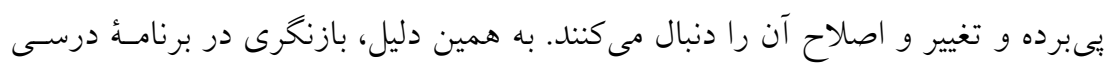
كارورزى دانشخاه فرهنگيان به عنوان نقطه عطفى در آموزش حرفهاى دانشسجو معلمـان

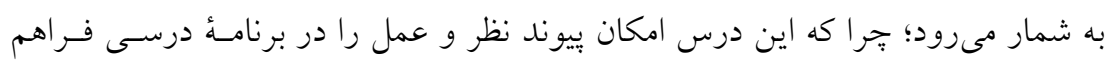

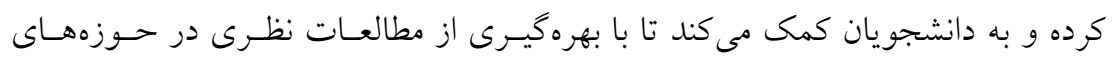

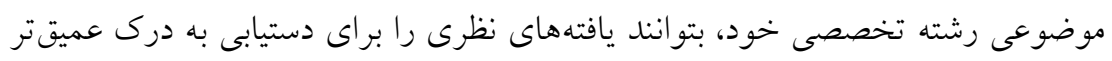

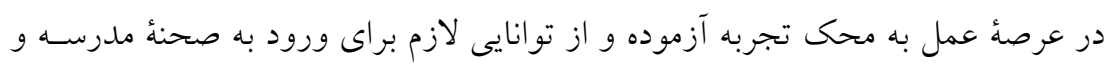

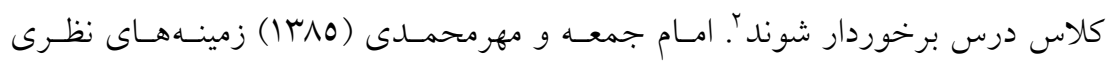
تربيت معلم (تربيت معلمان فكور) را مورد كاوش قرار دادهاند و روانشناسى وجودگراى

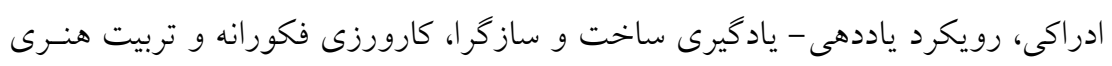

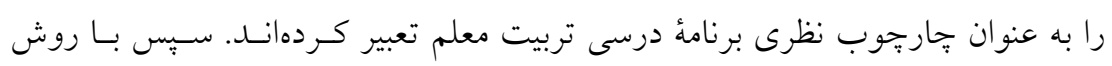

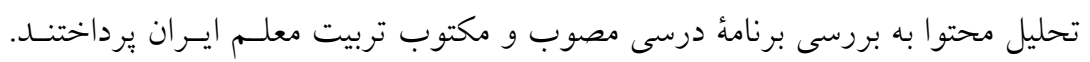

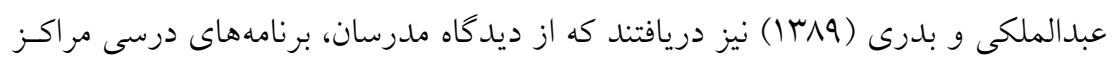

1 Eisner

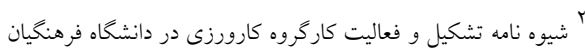


با صلاحيتهاى دانشى تناسب دارد ولى بـا صـلاحيت هـاى مهـارتى و نغرشى و كـل صلاحيت ها تناسب ندارد.

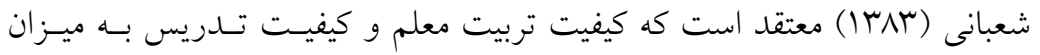

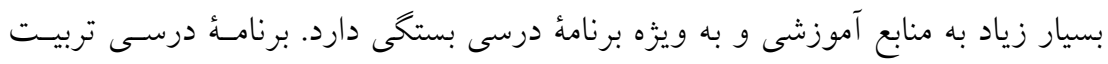

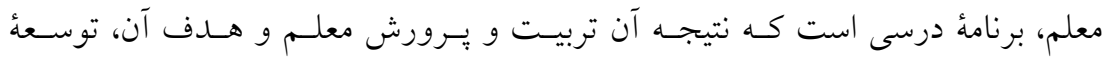

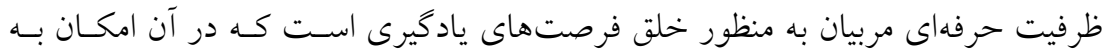

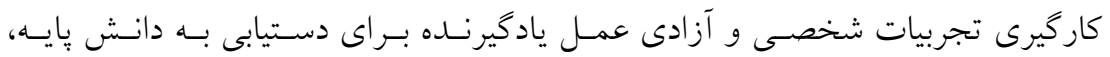

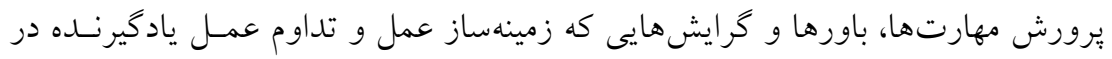

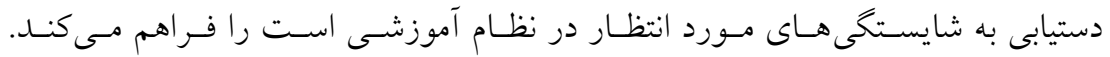

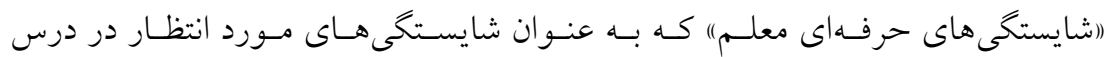

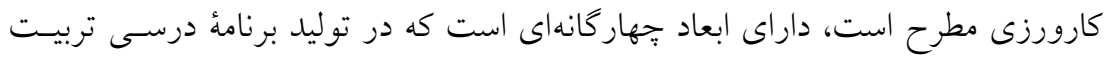

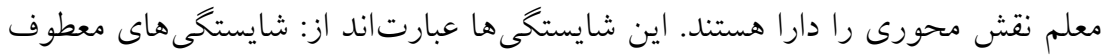

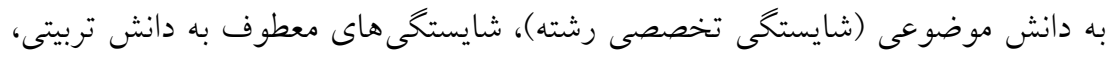

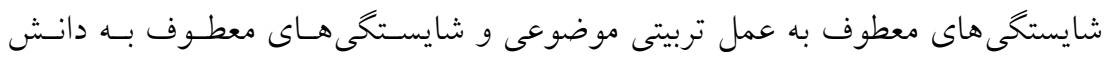

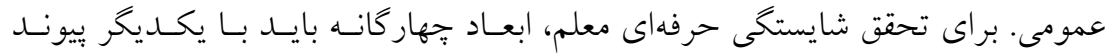

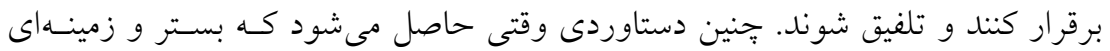
براى تلفيق فراهم شود و اين زمينه را (كارورزى) مهيا مى كند '.

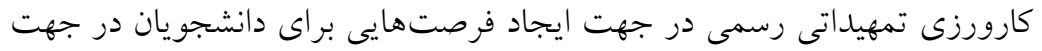

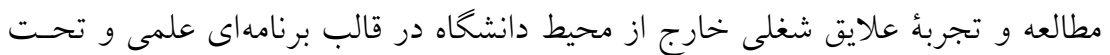

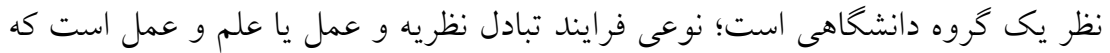

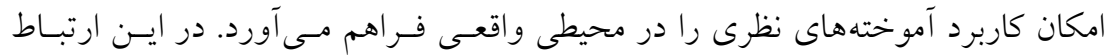

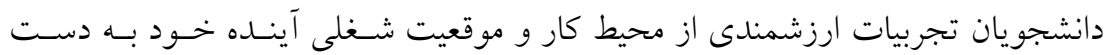

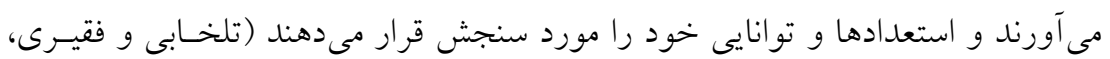

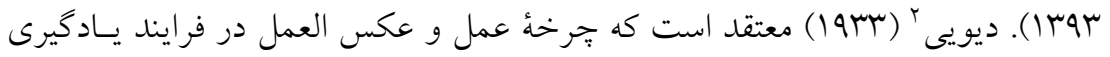

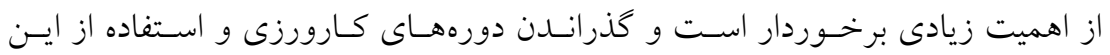

' معاونت آموزشى وتحصيلات تكميلى دانشكاه فرهنكيان. مشخصات كلى، برنامه و سرفصل دروس دوره كارشناسى بيوسته آذر ماه سوبا. 2 Dewey 
تبيين يديدارشناسانهُ اصول برنامهُ درسى ("تجربه تدريس)...

تجربه هاى عملى بسيار با ارزش است. شون' (1994) نيز به اين نتيجه رسيده اسـت كـه

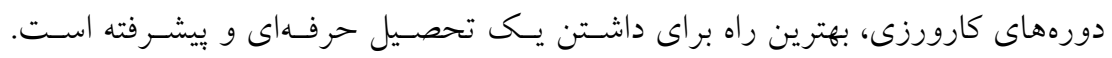

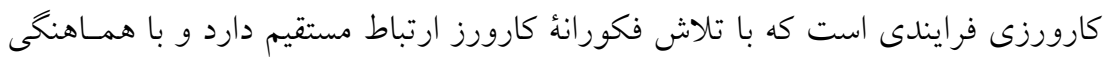

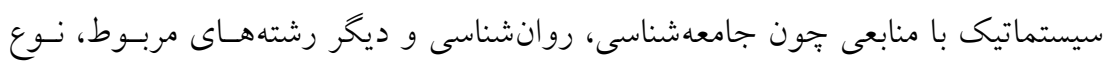
خاصى از روش تحصيلى را به وجود مى آورد كه منجر به كسـب تجربيـات مـورد نيـاز

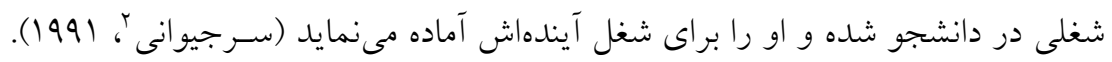

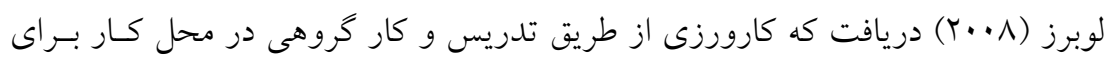
اجتماعى شدن دانشجويان مفيد بوده است. همجينين كنن و آرنولد (1991) به اين نتيجه رسيدند كه كارورزى درى عميقى از ماهيت شغل به كارورز داده و راه را براى استخدام دائمى وى هموار مى سازد. يافتههاى مايهيل نشان مىدهـد كـه كـارورزى مهارتهـاى

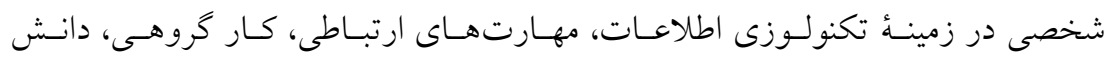

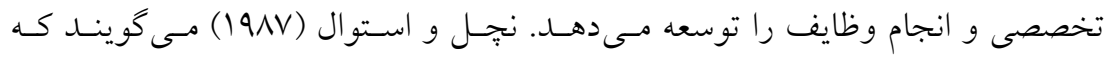
كارورزى دانش محتوايى كار را افزايش مىدهد. نورت (1910) نيز بر اين باور است كه

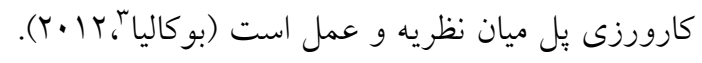

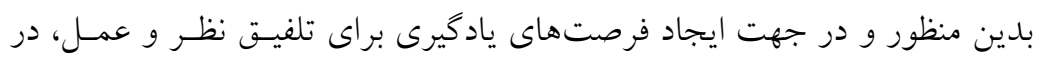

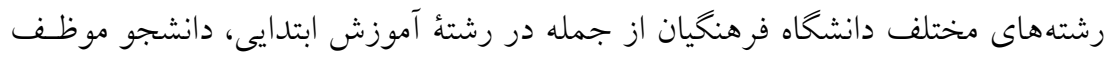

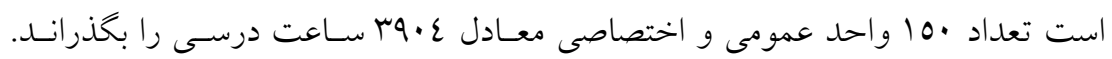
نخاهى به جدول دروس تخصصى نشان مىدهد كه از مجموع ra 911 واحسد تخصصسى

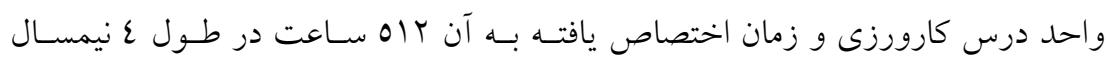

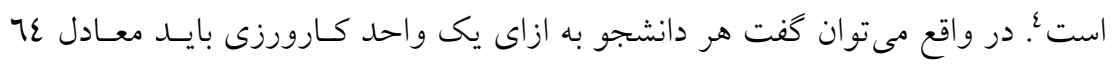
ساعت را در مراكز آموزشى مختلف زير نظر معلمان و اساتيد راهنما به فعاليت بيردازد.

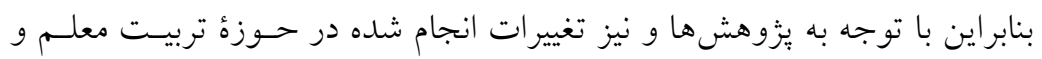

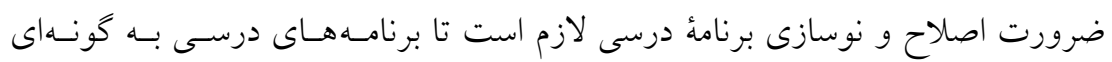

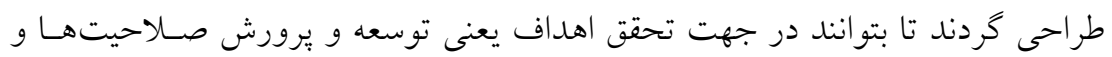

1 Schon

2 Sergiovanni

3 Bukalia

" معاونت آموزشى وتحصيلات تكميلى دانشكاه فرهنگيان. مشخصات كلى، برنامه و سرفصل دروس دوره كارشناسى يبيوسته آذر

ماه 
شايستخىهاى معلمى بيش روند. حال يرسشى كه در اينجا مطرح مى گردد اين است كه هـ

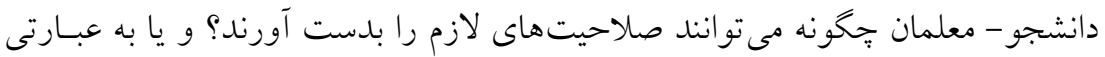

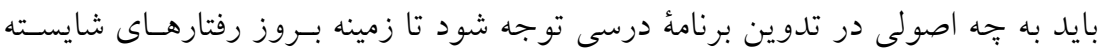

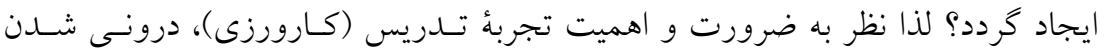

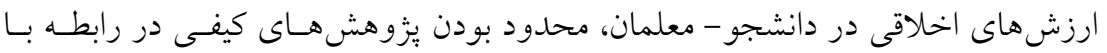

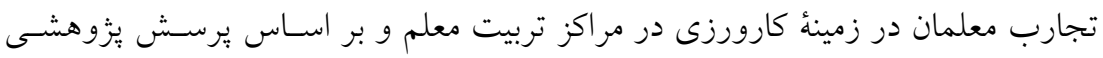

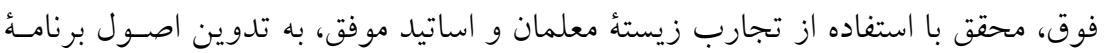

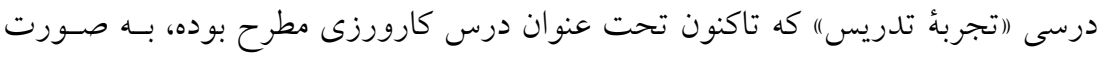

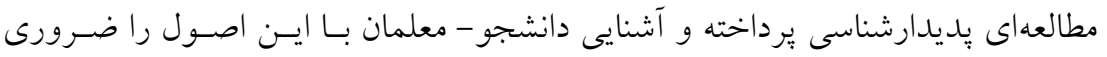

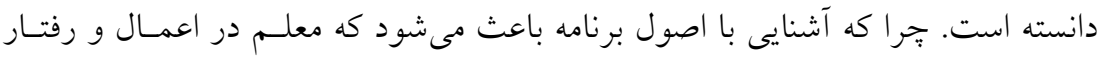

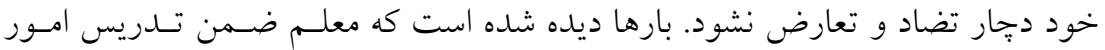

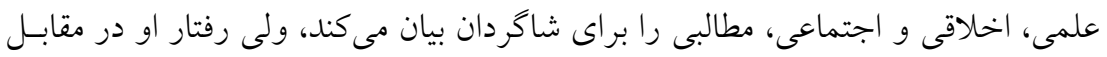

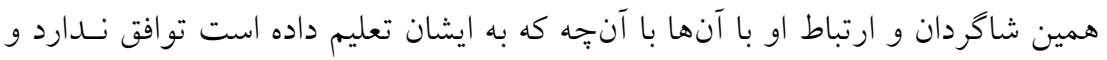

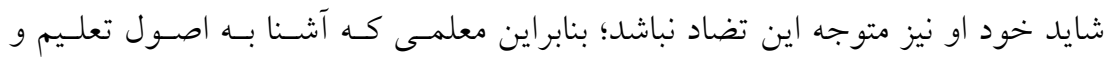

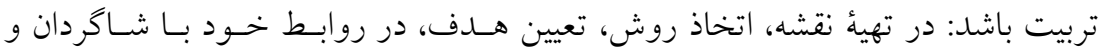

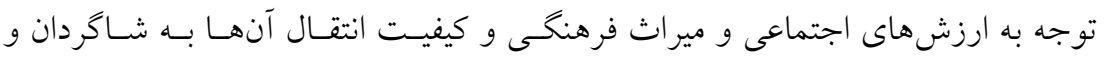

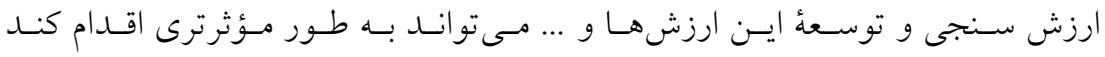

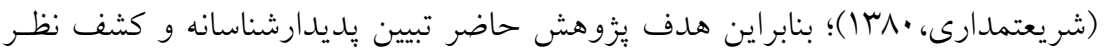

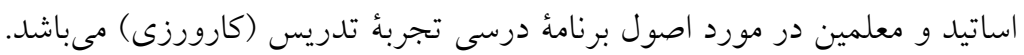

\section{روش بزّوهش}

اين يزوهش، به صورت مطالعهاى كيفى از نوع بديد بدرارشناسى طراحى كرديده است.

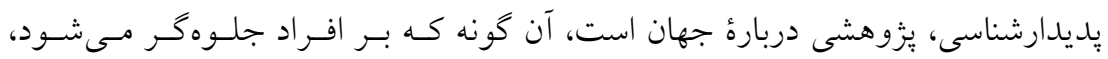

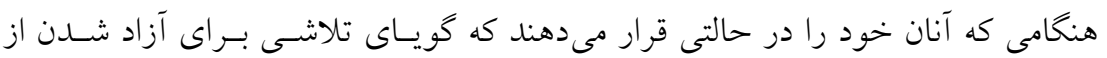

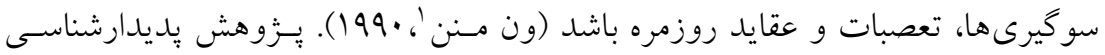

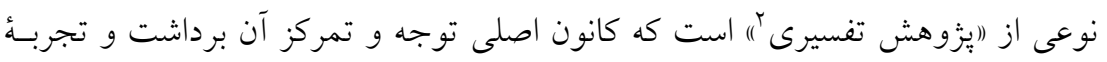


تبيين يديدارشناسانهُ اصول برنامهُ درسى ("تجربه تدريس)...

انسان مىباشد. يُزوهش يديدارشناختى برداشت هاى انسـانى افـراد مختلـفـ را بـهـ طـور مجزا بررسى كرده و نيز نتايج و توصيفهاى حاصل از اين برداشتها را بدانسـان كـه در برداشتهاى افراد به طور مستقيم ظاهر مىشود، بررسى مى نمايد (ياينار '،ع +. ب). روش انتخاب شركت كنند كان در اين بزوهش، به صورت هدفمند بوده اسـت كـه

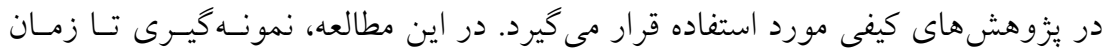
اشباع دادهها ادامه بيدا كرد كه با انجام نه مصاحبه با اساتيد و معلمــان موفـق، مجـرب و و داراى تحصيلات كارشناسى ارشد و دكترى تخصصسى، اشـباع دادههـا حاصـل كرديــ. روش جمع آورى اطلاعات، مصاحبة عميق ب بود كه با رويكردى تحليلى تجزيه و تحليل شد. سئوالات مصاحبه به صورت باز ياسخ و بر اساس راهنماى مصاحبه بود. به منظـور تجزيه و تحليل دادهها نيز از روش كدگَذارى موضـوعى بَ اسـتفاده شـده اسـت. بـــين ترتيب متن مصاحبه ها به طور كامل ضبط كرديد. يس از ضبط، مصاحبه ها بر روى كاغذ

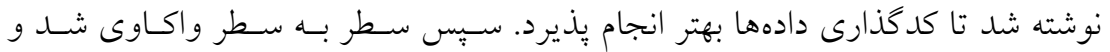
مفاهيم اصلى به صورت كد استخراج كرديد. يسـس از اسـتخراج كـدهاى اوليسه، محقـق كدهاى مشابه با يكديخر را ادغام و آنها را در گروهى قرار داد و براى هر طبقه نامى كه

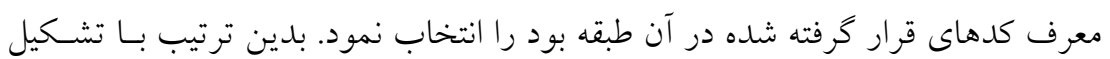
طبقهبندى، تمهاى اصلى مطالعه اسـتخراج كرديــد. بــراى اطمينـان از صـحت و ويايـايى تحقيق، متن مصاحبهها و مفاهيم استخراج شده از آنها به شـركت كنتـدكان باز گردانــده

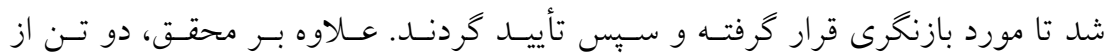
مدرسين آشنا با تحقيق كيفى، متون و مفاهيم را نيز مـورد بــازنخرى قـرار دادنــ كـه تـا حدود •9 درصد در مورد مفاهيم اتفاق نظر وجود داشت. همجنين نتايج اين مطالعسه در اختيار معلمان موفق ديخرى كه در طرح شركت نداشتند، قرار كرفت آنها نيز بـا توجـه به تجارب خود اين نتايج را تأييد كردند.

${ }^{1}$ Pinar

2In depth interview

3Thematic coding 
دو فصلنامه نظريه و عمل در برنامه درسى، شماره 7، سال سوم، ياييز و زمستان عوبا

جدول ( (1): ويزگ گىهاى جامعهشناختى مصاحبهشوندكان

\begin{tabular}{|c|c|c|c|c|c|}
\hline محل تدريس & تدريس & مرتبهُ علمى & رتحسلى & تحـــــــــ & $\hat{a}^{\circ}$ \\
\hline فارسى كازرون & 9 & استاديار & روانشناسى & دكترى & 1 \\
\hline فربيرسـتان و دانشــاه & ro & دبير و مدرس & آموزنامسهريـــى & 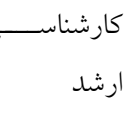 & $r$ \\
\hline فربيرســان و دانشــاه & r & دبير و مدرس & 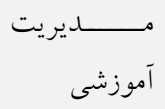 & 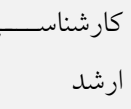 & $r$ \\
\hline دانشخاه فرهنگيان & 9 & مدرس & روانشناسى & دكترى & $\varepsilon$ \\
\hline دانشگاه شيراز & $1 r$ & استاديار & فلسفه تعلسيم & دكترى & 0 \\
\hline اصفانشـاه خوراسـحان & 10 & استاديار & 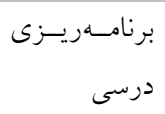 & دكترى & 7 \\
\hline دانشــاه خوراســان & 7 & استاديار & برنامسهريـزى & دكترى & V \\
\hline دانشخاه اصفهان & rl & دانشيار & برنامسهريـزى & دكترى & $\wedge$ \\
\hline دانشخاه بوشهر & ro & دبير و مدرس & ادبيات & دكترى & 9 \\
\hline
\end{tabular}

يافتهها

يافتههاى حاصل از اين بزوهش بعد از حذف كدهاى مشترك، بـ كد مفهومى كـه

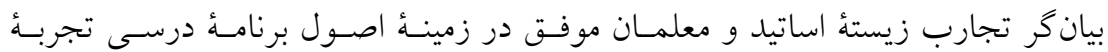
تدريس بود، استخراج كرديد. اين مفاهيم در هشت مؤلفهُ اصلى: تعامـل غــم خوارانـه و مهرورزانه، يويايى، تدبير تدريس، خويشتن نخرى، كنش متقـابلى، ايجـاد موقعيـتهــاى

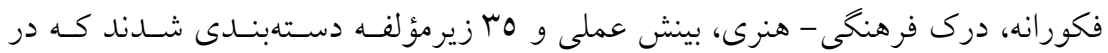
نمودار (1) نشان داده شده است: 
تبيين يديدارشناسانهُ اصول برنامهٔ درسى ((تجربه تدريس)...

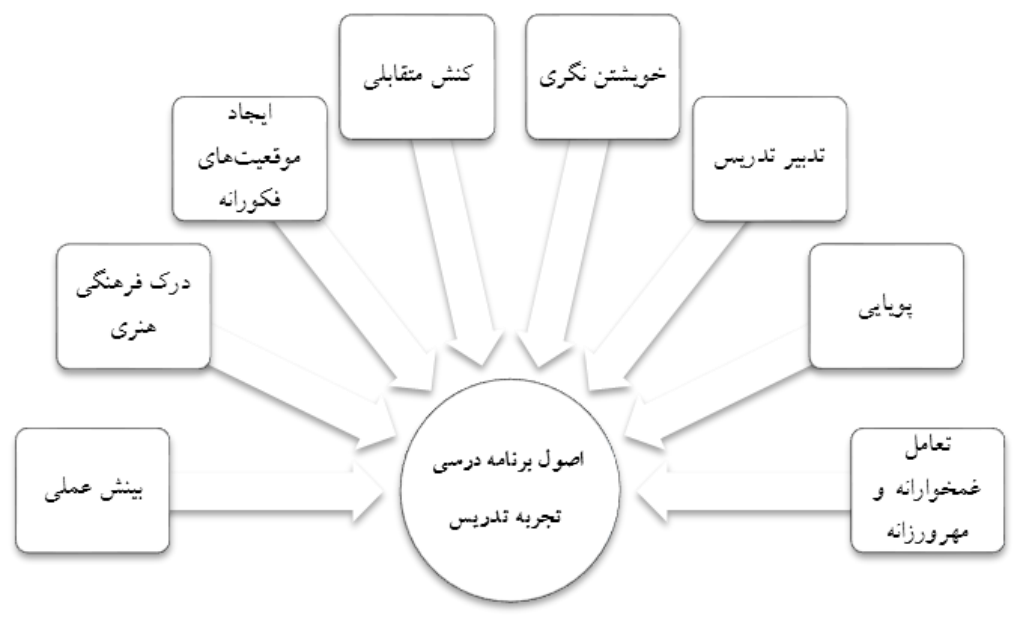

نمودار ( (1) اصول برنامهٔ درسى تجربهُ تدريس بر اساس تجارب زيستهُ معلمان موفق

\section{ا.تعامل غمخوارانه و مهرورزانه'}

مفاهيم استخراج شده از مصاحبه ها در اين زمينهُ اصـلى داراى جهـار كــ مفهـومى

فرعى به شرح مندرج در نمودار (Y) است.

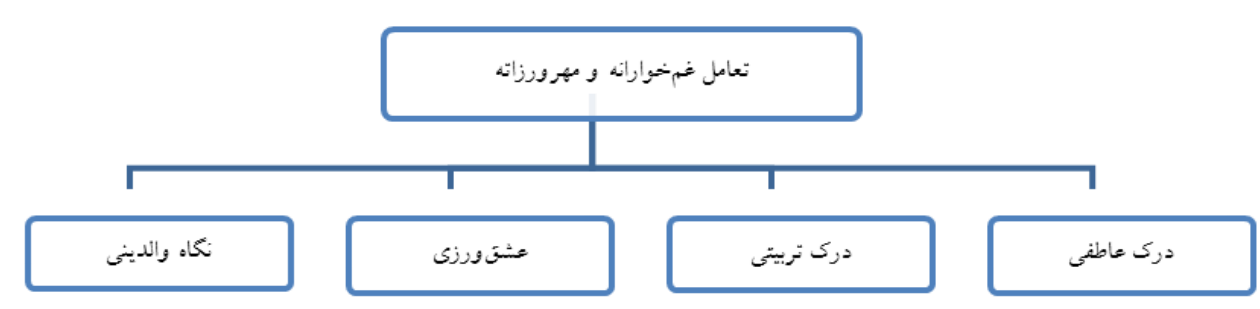

نمودار (Y) تجارب معلمان در زمينه اصول برنامهٔ درسى تجربهُ تدريس (اصل: تعامل مبتنى

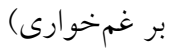

1 sympathetic and kind interaction 
مولوى، برشورترين شاعر ايرانى در زمينه موضوع عشق، به مهربـانى و مهرورزى

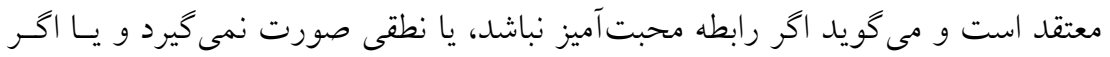

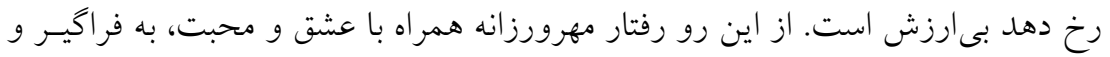

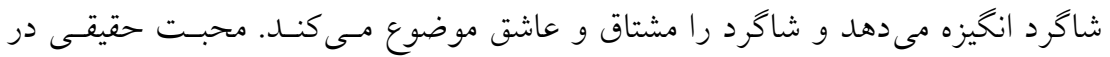

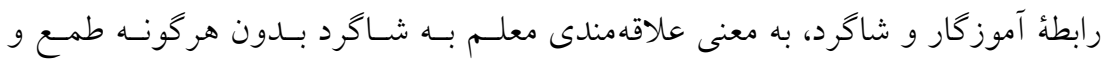

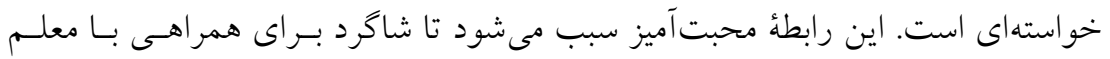

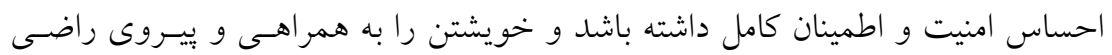

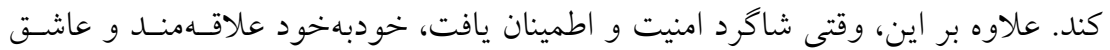

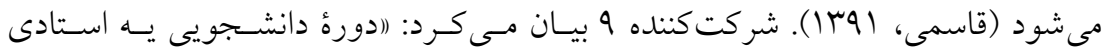
داشتيم به نام دكتر (ن). دكتر (ن) خيلى منو دوست داشـت. وقـت اسـتراحت، تـو اتـاق

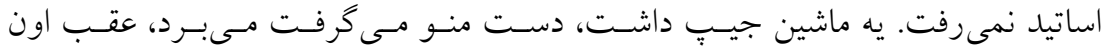
مىنشوند، خايى و بيسكويت هم تعارف مى كرد. مى كفت فلانى شعرات رو برام بخــون

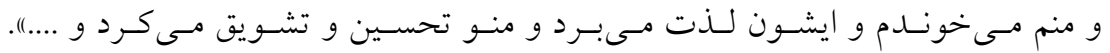

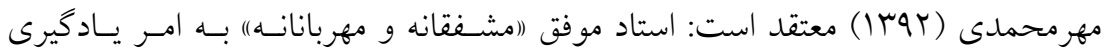

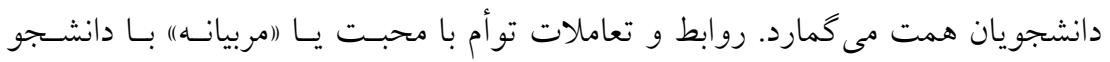

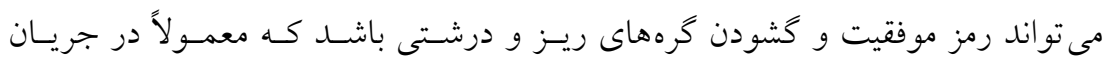

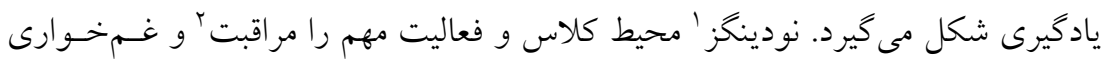

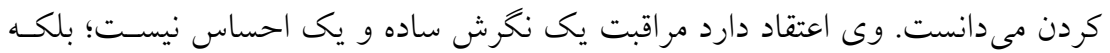

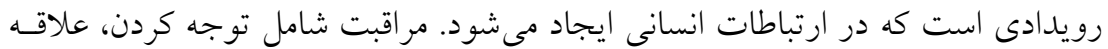

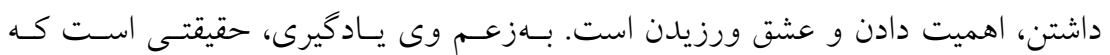

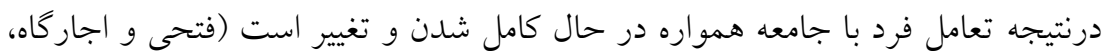


تبيين يديدارشناسانهُ اصول برنامهُ درسى ("تجربه تدريس)...

\section{Y.يويايى}

مفاهيم استخراج شده از مصاحبه ها در اين زمينهُ اصـلى داراى جهــار كـد مفهـومى

$$
\text { فرعى به شرح مندرج در نمودار (r) است. }
$$

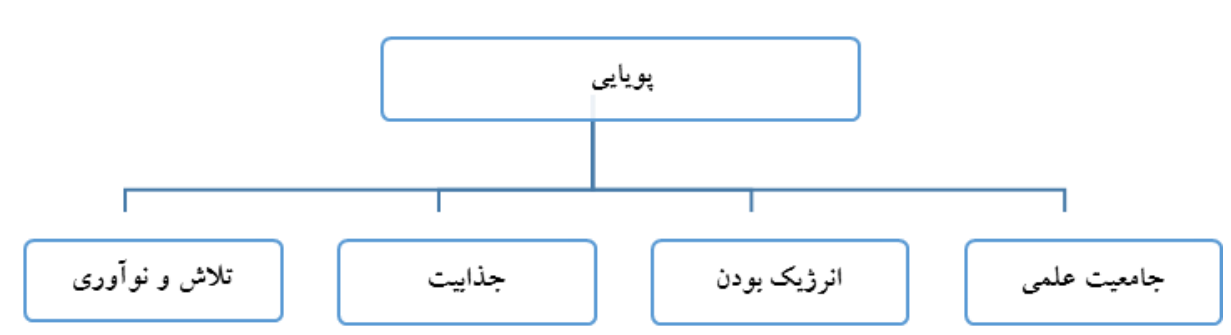

نمودار (r) تجارب معلمان در زمينه اصول برنامهُ درسى تجربهُ تدريس (اصل: يويايى)

استاد موفق مىتواند در عين جدى بودن، محيط كلاس را شـاداب و فرحنـاك نخـه. دارد. لذت را بايد علاوه بر راه دستيابى به قلب و احساس، راه دستيابى به عقل و ذهـن

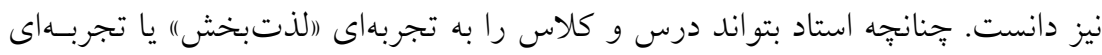

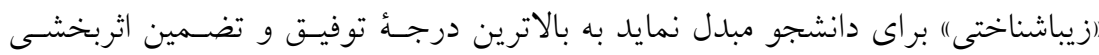

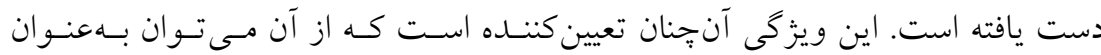
شاخص قطعى (سلامت) فرايند ياددهى - يـادگيرى بهـره جسـت. برخـوردارى فراينــ

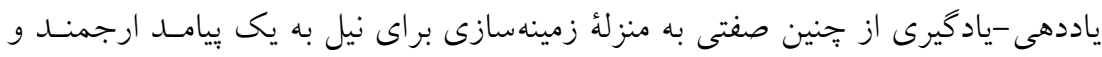

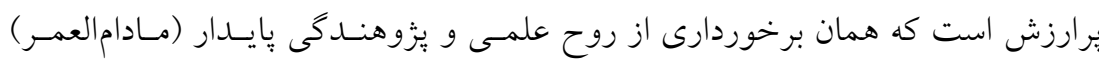

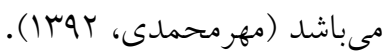
شركت كنندهُ ץ بيان مى كرد: (ادرس عربى رو يادمه خيلى طنز قاطى مى كردند. ولى

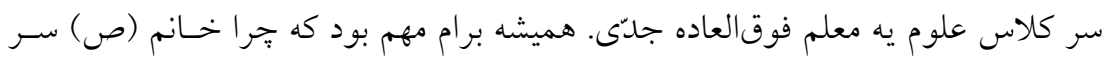
كلاس علوم اين جوريه ولى سر كاس عربى اون جورى؟ يادمه سر كلاس علـوم يكسى از بجزهها، يه شوخى خيلى جمع و جورى كردند، خيلى ناراحت شد. كفت بتجه ها وقتى

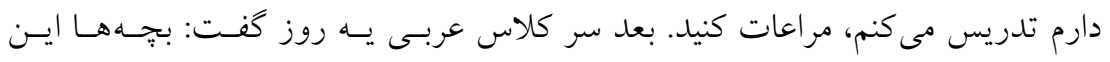

1dynamism 
عبارت بر وزن جيه؟ من هم فورى كفتم به قول بِدر من: ضرب، ضربا، ضربوا، كَفَتَر در

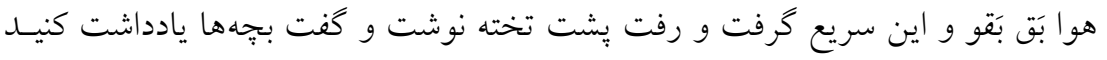

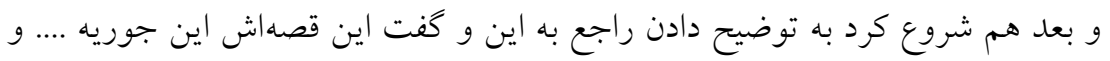

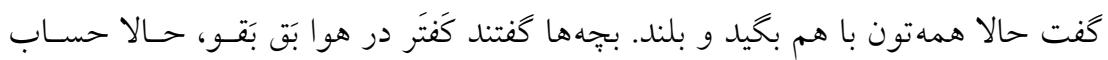
كنيد كل كلاس داشت مىتركيد از ذوق و خندهاه ).

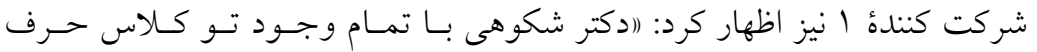

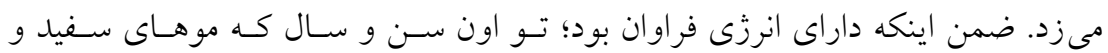

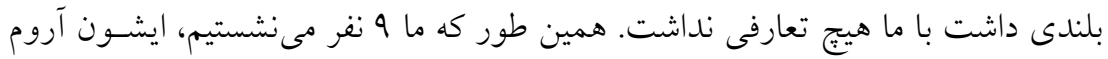

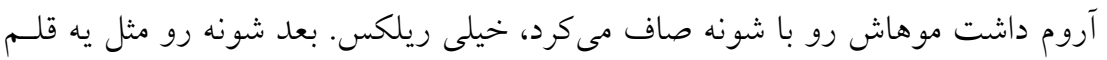

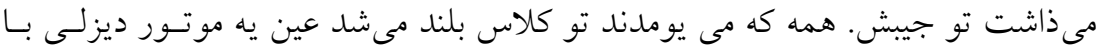

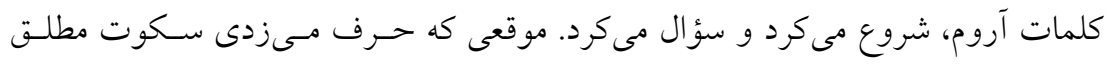

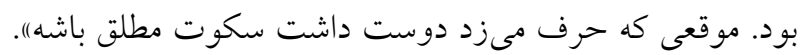
r.تدبير تدريس

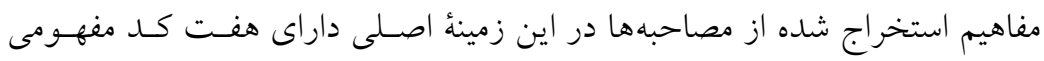
فرعى به شرح مندرج در نمودار (ع) است.

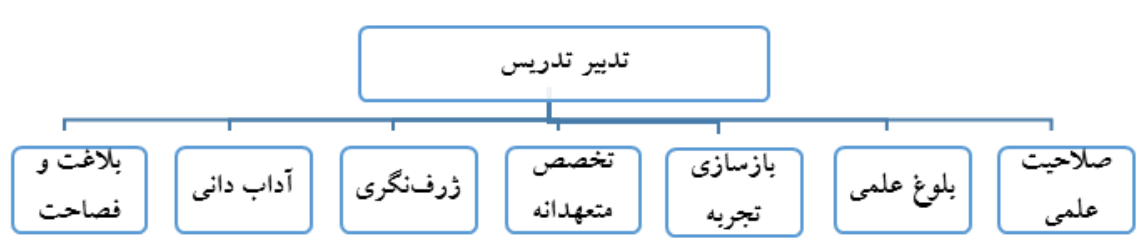

نمو دار (ع) تجارب معلمان در زمينة اصول برنامةٔ درسى تجربأ تدريس (اصل: تدبير

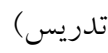

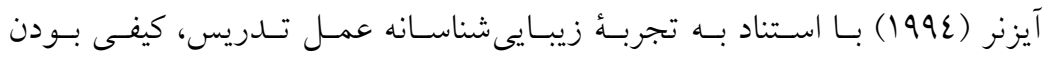

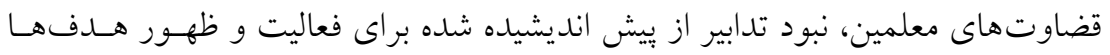

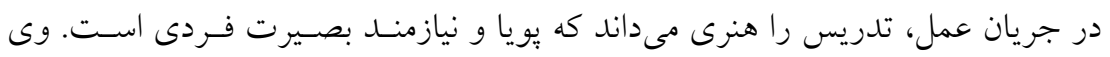

1 tact of teaching 


\section{تبيين يديدارشناسانهُ اصول برنامهُ درسى ("تجربه تدريس)...}

معتقد است تدريس يك فعاليت موقعيتى است كه معلم به شيوهاى هنرمندانه، ابتكارى و ويزه به آن نظر دارد و عمل مى كند؛ بنابراين معلمى كردن با ادراك دقيق موقعيت همــراه است و البته جنين دركى جشــمى تيـزبين لازم دارد. در همسين راسـتا شـركت كنتـدهُ ب مى كفت: اروَشِشون توضيحى تو أم با فعاليت بود. مطالب كتاب رو بحث مى كـردن؛ امـا همهُ ما رو موظف مىكردند كه قبلش كتاب رو بخونيم يعنى با مطالعه بيايم سـر كـلاس و بعد همون مطالب رو با روش فعاليت بحث كردن دنبال مى كرد و خيلى هــم تواضـع داشت در اين كه بعضى جاهاش وانمود مى كرد خودش به خوبى نمىتونه تبيسين بكنـه. مثلاً من يادمه يك الكوى cipp تو ارزشيابى بود. آقاى دكتر مسعودى اومد تو كلاس به

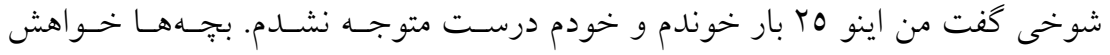
مى كنم با هم بخونيد ببينيد متوجه نمى شيد. بعل ما متوجه شـديم خـوب فهميـله جـون موضوعش يه خورده بيّيجيده بوده، خواست كه همه رو وادار كنه به فكر كـردن كـه اخـر شما فكر كنيد و يا ما فكر كنيم حتى مطالب بيجيجيده رو مىشه آموزش داد.)

مهر محمدى (Y (IT) يكى از كفايتهاى اساسى تدريس را اقتدار مى داند و معتقـد است داشتن تسلط علمى به موضوع يكى از لوازم اقتدار است كه بايد با تسلط آموزشى تركيب و تكميل شود. برخلاف تصور رايج، نه تنها اين نوع اقتدار با اقرار به جاو تـوأم با صداقت ((ندانستن) زايل نمى شود، بلكه جهه بسا با جنين اعترافى بـر اقتـدار معنـوى و حرفهاى استاد نيز افزوده مى گردد.

\section{ع.خويشتن نخرى}

مفاهيم استخراج شده از مصاحبه ها در اين زمينهُ اصـلى داراى جهــار كـــ مفهـومى فرعى به شرح مندرج در نمودار (0) است.

1introspection 


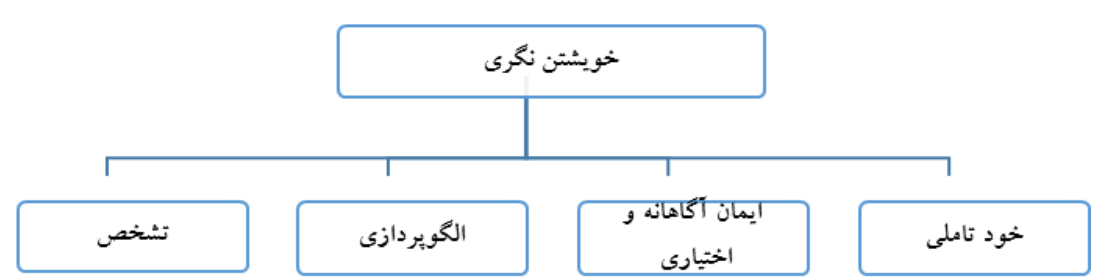

نمودار (0) تجارب معلمان در زمينهُ اصول برنامئ درسى تجربئ تدريس (اصـل: خويشـت

تأمل در لغت به معناى ((نيك نخريستن) و (انديشه كردن) قلمداد شده؛ نـوعى فعـل شخصى است كه اتفاقى را در درون سبب مى شـود؛ هرجنــ ممكـن اسـت ايسن پيديـده درونى داراى جلوهاى آشكار در بيرون هــم باشـــ. همسين وجـهـ تأمـل اسـت كـه آن را موضوعى مربوط به شخص مى سازد و همة امور مختلف شخصى را بوشش مى دهــد، از

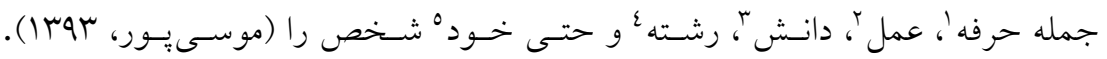
شركت كنندهُ ه بيان مى كرد: (امعلم دينى و خانهدارىمـون خيلسى بـا شخصـيت بــود. بـا وجودى كه من دبيرستانم دورة شاه بود و اكثر معلماى ما بى حجاب بودند ولى من هـيج وقت نديدم كه اين خانم بِاى بدون جوراب بياد. هيج وقت نديسـدم ايسن خـانم بِيـراهن آستين كوتاه تنش باشه يا دامن كوتاه ياش كنه. هيج وقت نديدم كفش بِاشنه بلند بيوشه. هيج وقت نديدم اين موهاش را بيخودى بييجه. ايشون هيج وقت آرايش نمى كرد. خيلى ساده ولى شيك و مرتب بود. بجزهه ها خيلى دوسـتش داشـتند. خــودش هـم يــه ارتبـاط

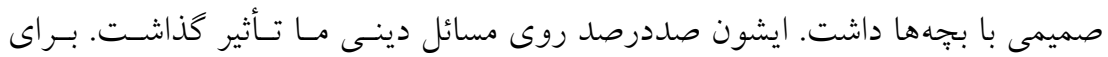
اينكه با اعتقاد حرف مىزد. خيلى با اعتقاد. براى اينكه ما مىدونستيم حتمـاً ايشـون مـاه رمضون، روزه مى گيره. هيج وقت نديديم تو ماه رمضون، آب بخوره. هيج وقت از ايسن

1 profession

2 Action

3 knowledge

4 Discipline

5 self 
تبيين يديدارشناسانهُ اصول برنامهُ درسى ("تجربه تدريس)...

دروغ نشنيديم. هيج وقت سر كلاس غيبت همكاراى ديخه شـو نمسى كـرد. هـيج وقـت لباس جلف نمى يوشيد. هيج وقت بلند نمى خنديد. با هيج همكار ديخرى داخل مدرسه،

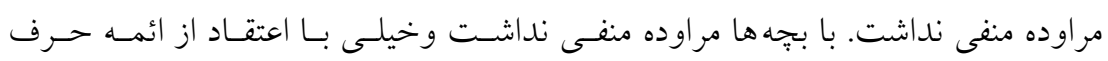
مى زد.) استاد موفق با خويشتن و دانشجويان برمبناى ((منش صداقت و يكرنخىى) عمـل مى كند. استادان تازهكار ممكن است تظاهر به جِنين منشى بكنند؛ اما دانشـجو انسـان دو رو را خيلى زود تشخيص مىدهد و از استاد متظاهر روى برمىتابد. اين موضوع آن قدر حائز اهميت است كه كفته شده كسى كه رفتار و سلوك بيـرون از كلاسـش بـا رفتـار و سلوك داخل كلاسش متفاوت است و نمىتو اند شخصيت يكهيارجه از خود بــروز دهـد، بهتر است در اين حرفه ادامه فعاليت ندهد (مهرمحمدى، بوبا (I).

\section{0.كنش متقابلى}

مفاهيم استخراج شده از مصاحبه ها در اين زمينـهُ اصـلى داراى يـنج كـــ مفهـومى فرعى به شرح مندرج در نمودار (7) است.

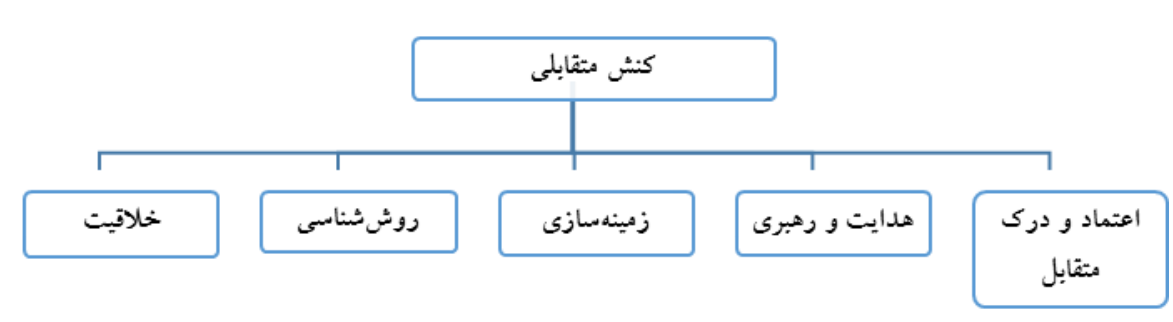

نمودار (7) تجارب معلمان در زمينة اصول برنامة درسى تجربة تدريس (اصل: كنش متقابلى)

1Mutual interaction 
توانايى برقرارى ارتباط مؤثر يكى از شاخص هاى مهم تدريس اثـر بخـش اسـت و

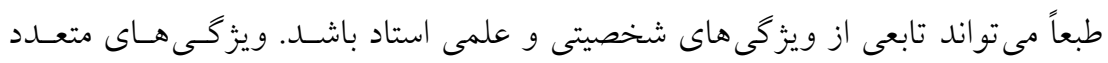

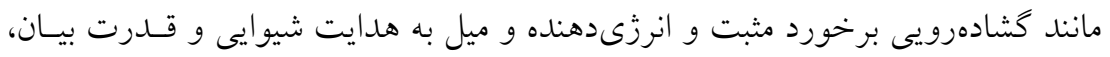

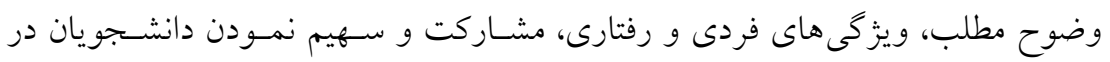

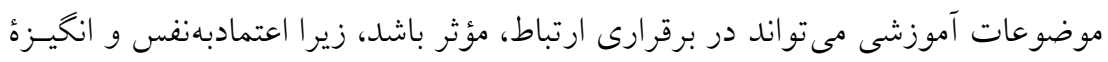

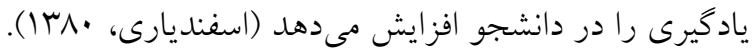

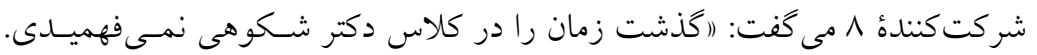

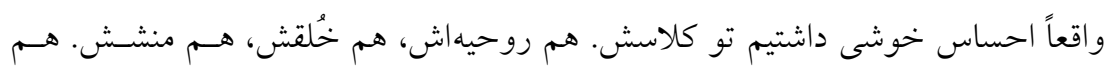
كار علميش، هم جذبه و جاذبهاى كه به لحاظ شخصيتى داشت. نحسوه درس دادنشـون،

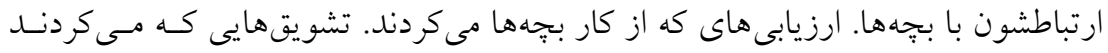

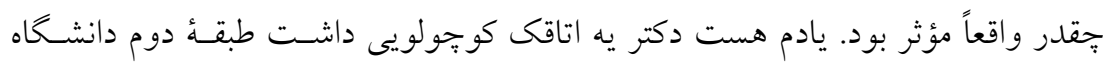

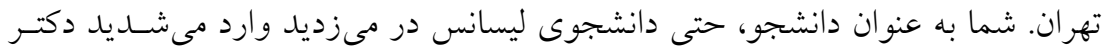

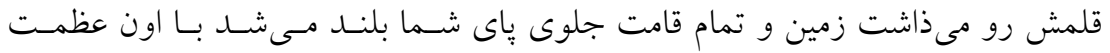

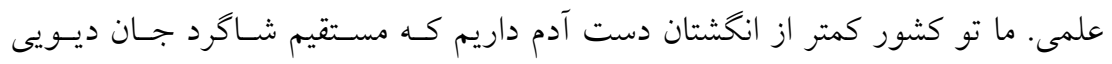
باشند، يكيش ايشون بوده ولى نشد يكبار به زبون بياره. يادمه يكى از همكلاسى هام يه دانه

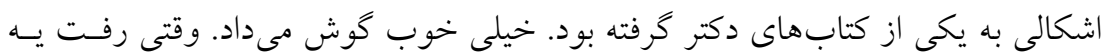

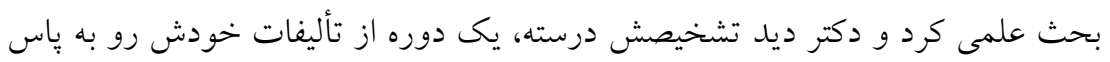

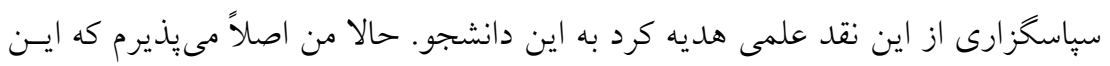

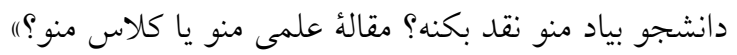

\section{7. ايجاد موقعيتهاى فكورانه'}

مفاهيم استخراج شده از مصاحبهها در اين زمينه اصلى داراى سه كد مفهومى فرعى

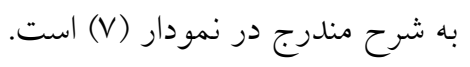

1Creating reflective situations 
تبيين يديدارشناسانهُ اصول برنامهُ درسى ("تجربه تدريس)...

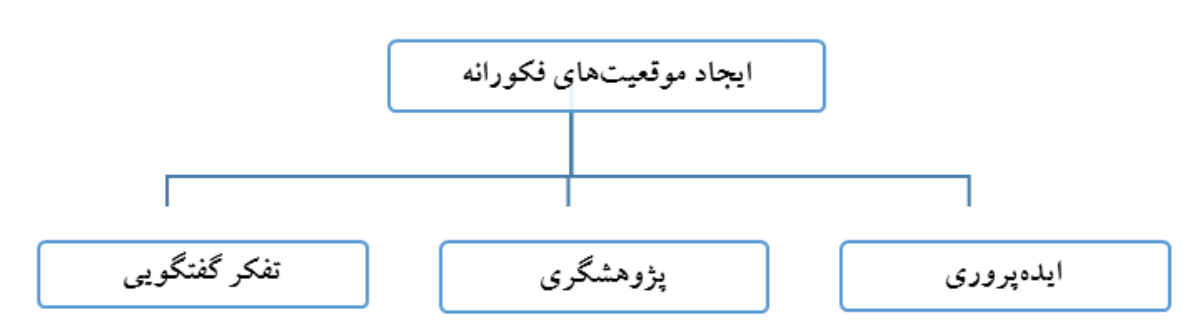

نمودار (V) تجارب معلمان در زمينهُ اصول برنامهُ درسى تجربهُ تدريس (اصل: ايجاد

موقعيت هاى فكورانه)

استاد موفق بايد خصلت يادگيرندگى را هرگز از دست ندهد. (استاد نمونه اسـتادى

است كه از نظر يادگيرى نمونه است.) استادى، جنانجهه بناست با توفيق قرين باشد، بايد با جهل و كوشش دائمى و مادام العمر همراه باشد. اين مهم بهويزه در عصر كنـونى كـه سرعت تغييرات در عرصههاى گوناگون دانش بشرى بىسابقه و غير قابل تصور است و

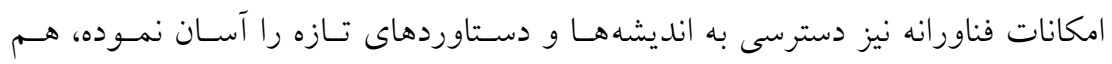
ضرورى تر و هم غفلت از آن نابخشودنى تر است. اين تعبير از يائولو فريره نيـز در ايسن جهت شنيدنى است كه استاد و مدرس حقيقى و رهـايى بخـش را (اسـتاد- دانشـجو) ) مى داند و به كارگيرى تعبير (اسـتاد) بــه تنهـايى را نادرسـت مسى انخـارد (مهرمحمـدى، rar (1). شركت كنندهُ ع اظهار مى كرد: ((ابزارهايى كه اون موقع بــراى تـدريس در اختيـار معلما بود، خيلى محدودتر از الان بود. كمتر مىتونستن از روش فعال تــريس اسـفاده كن. به تعبيرى محدود بودن به توانايى هاى خودشون. يادمه ايشون حتى جلسهُ معارفـه،

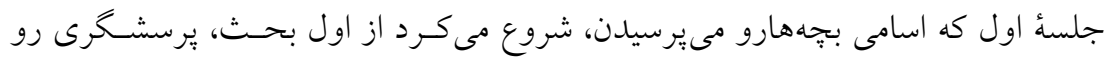
ياد مىدادن؛ يعنى مىيرسيد، آيا در مورد فاميل خودتون فكر كرديد؟ آيا مسىدونيـد ايسن

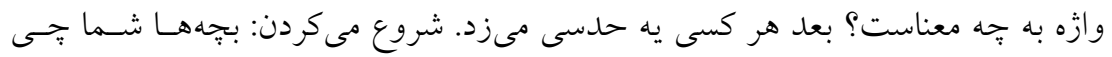
فكر مى كنيد؟ يعنى از ملموسترين ويزً گیى هايى كه شايد ما اصلاً بهش فكر نمسى كـرديم

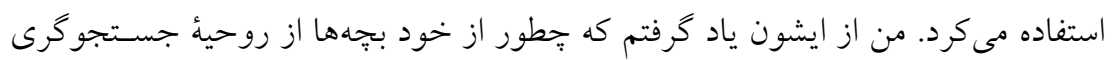

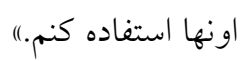




\section{V.درك فرهنكى هنرى'}

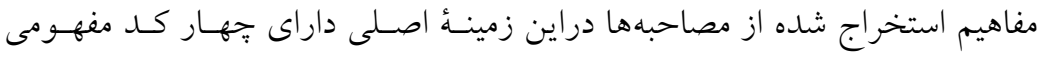
فرعى به شرح مندرج در نمودار (ᄉ) است.

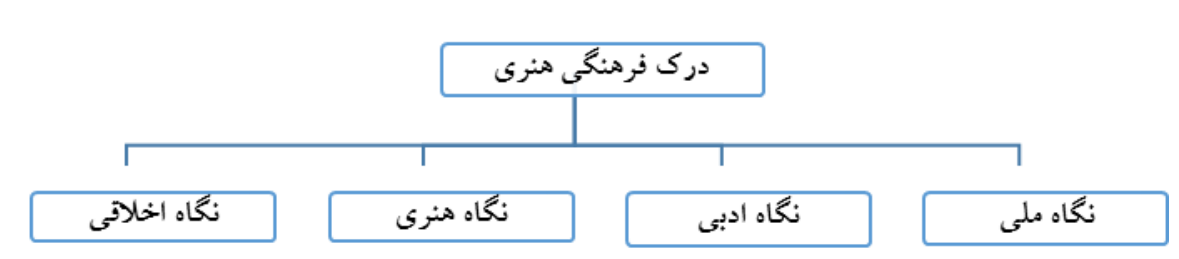

نمودار (^) تجارب معلمان در زمينة اصول برنامة درسى تجربأة تدريس (اصل: درى فرهنخى هنرى)

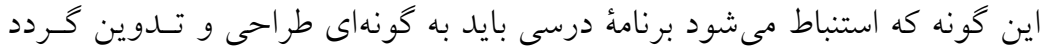

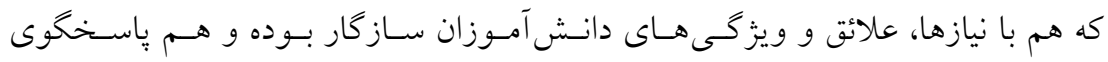

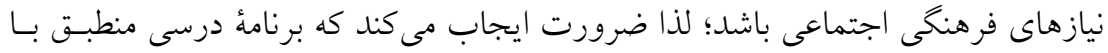

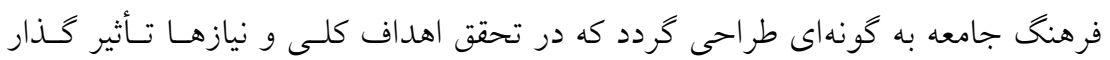

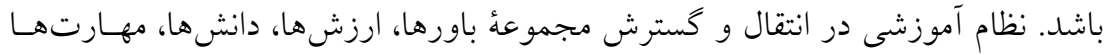

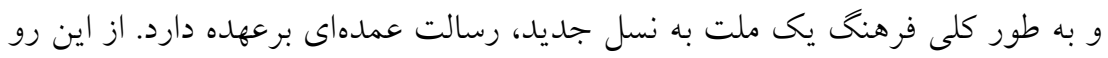

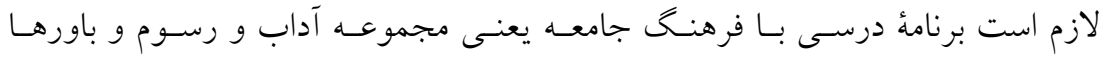

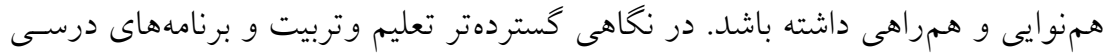

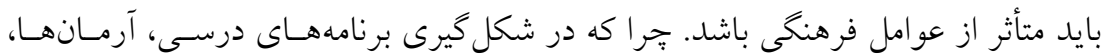

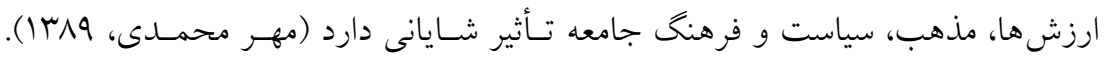

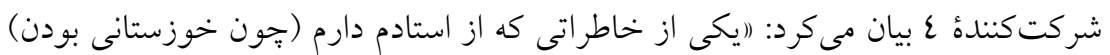

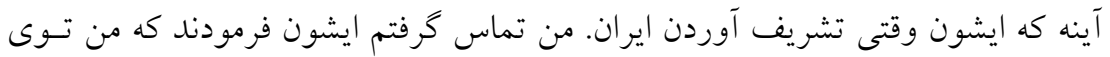

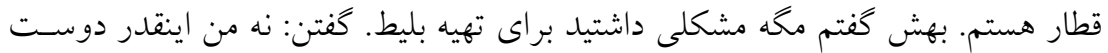

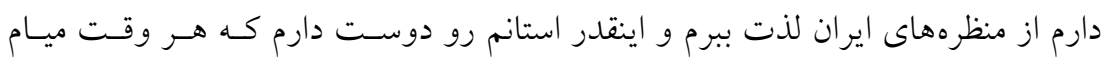

1 cultural-artistic understanding 
تبيين بديدارشناسانئ اصول برنامةٔ درسى (تجربه تدريس)...

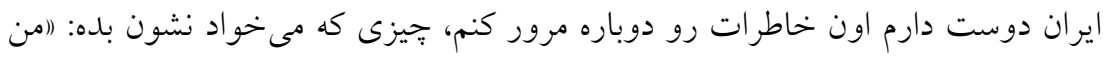

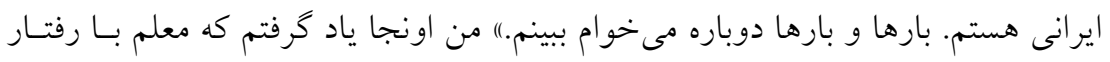

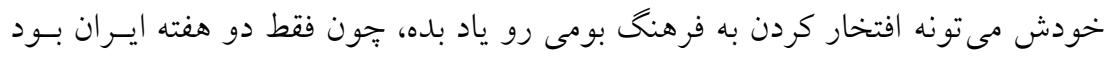

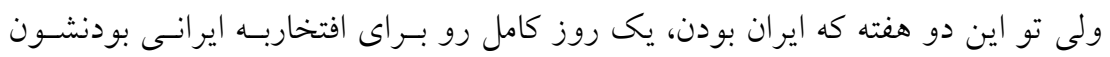

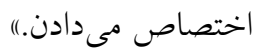

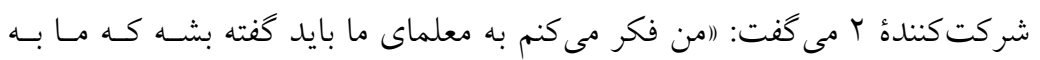

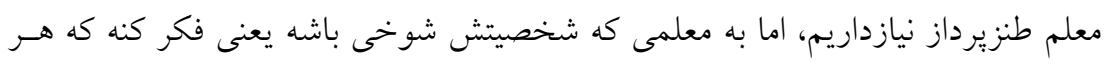

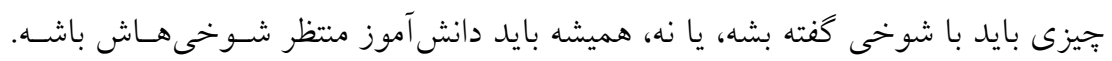

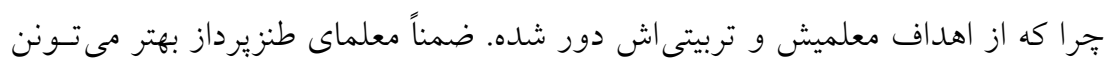

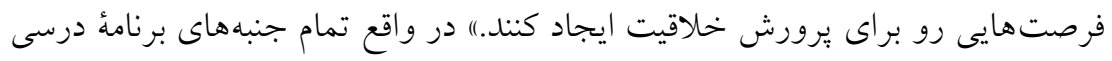

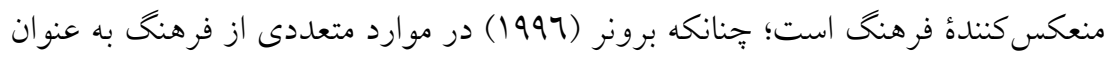

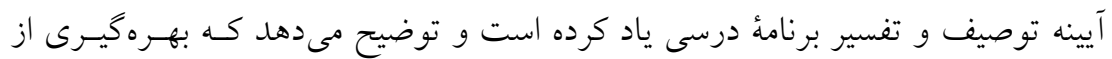

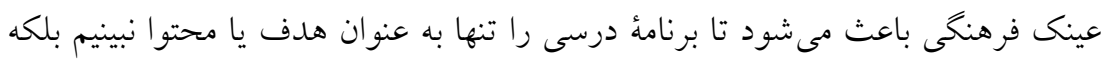

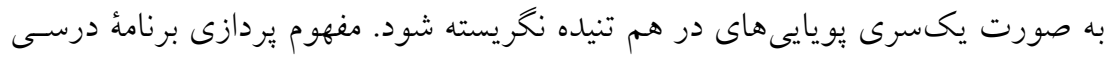

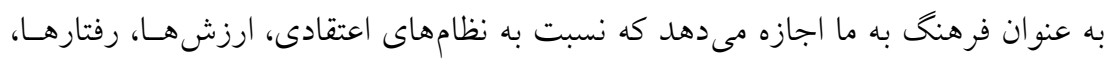

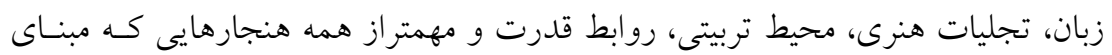

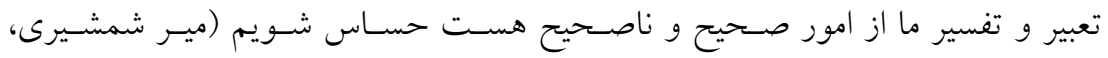

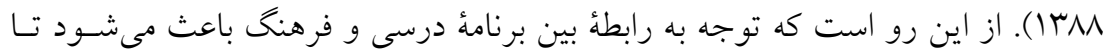

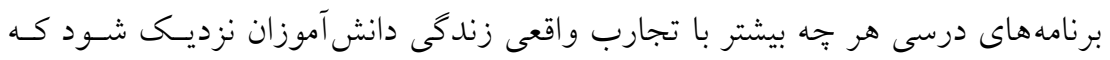

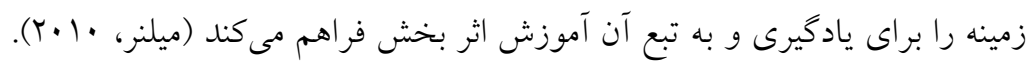

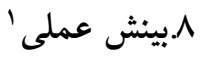

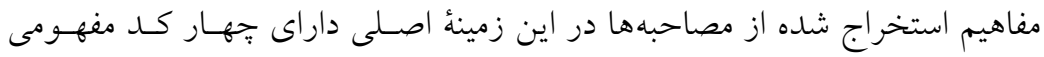
فرعى به شرح مندرج درنمودار (9) است.

1practical insight 


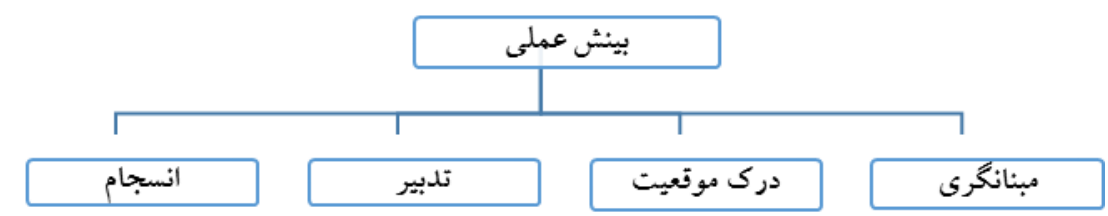

نمودار (9) تجارب معلمان در زمينة اصول برنامهُ درسى تجربهُ تدريس (اصل: بينش عملى )

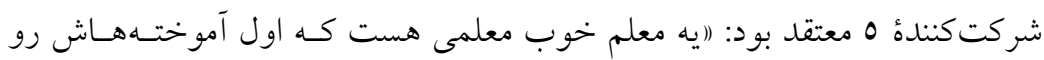

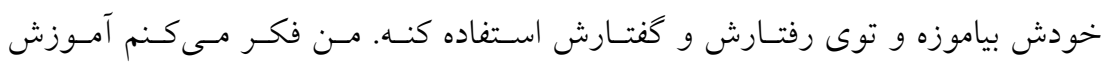

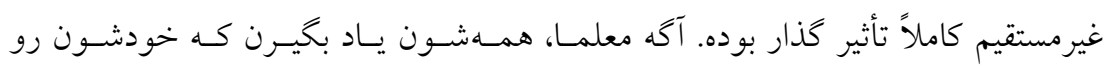

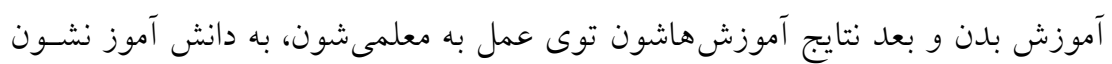

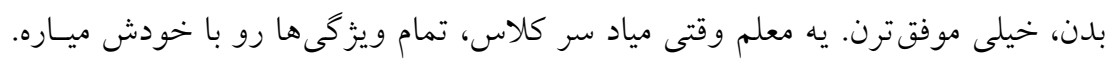

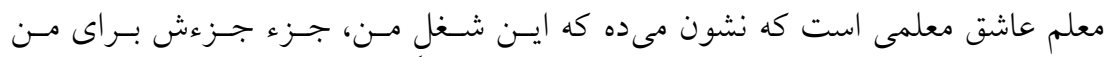

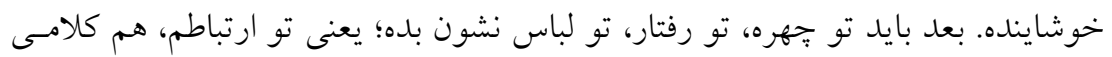

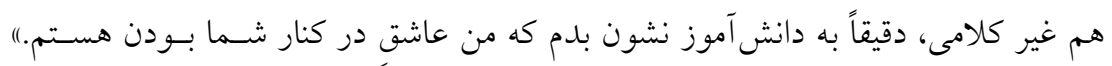

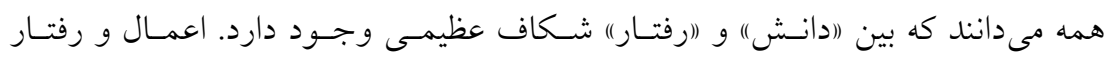

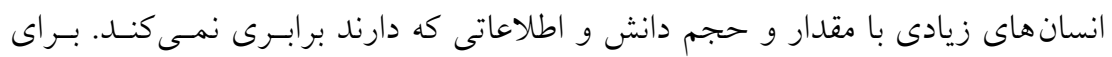

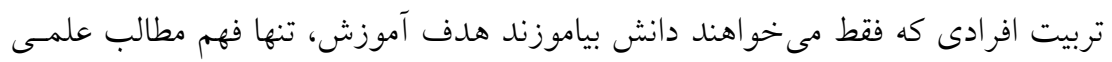

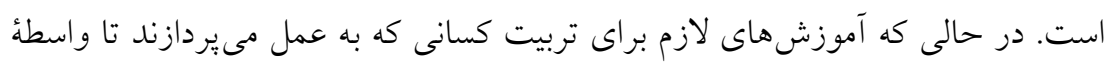

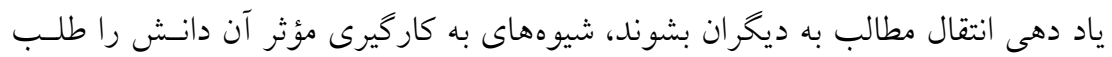

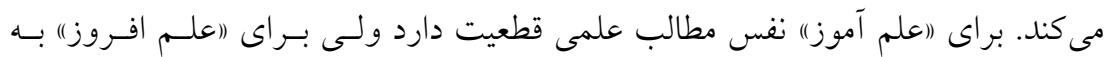

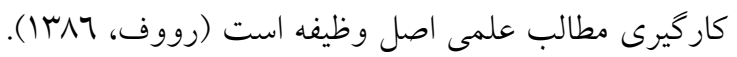


تبيين يديدارشناسانهُ اصول برنامهُ درسى ("تجربه تدريس)"..

\section{نتيجه كيرى}

معلمان كليدى ترين عنصر نظام تعليم و تربيت هستند. اهميت جايخاه و نقش معلم

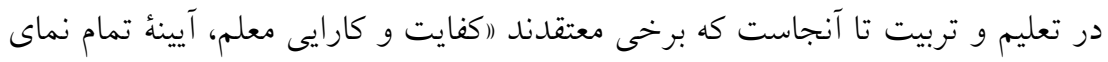

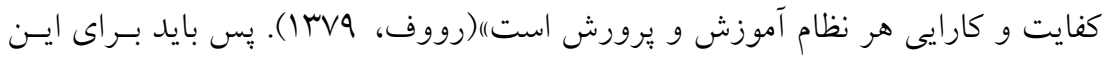

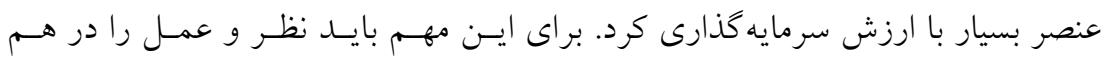

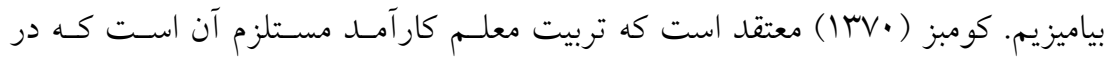

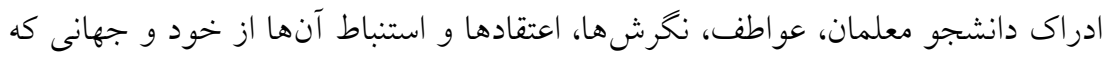

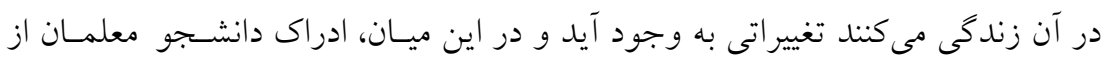

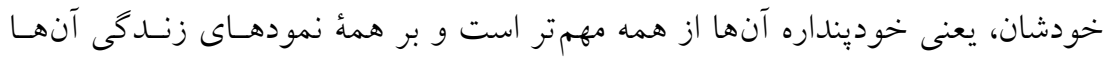

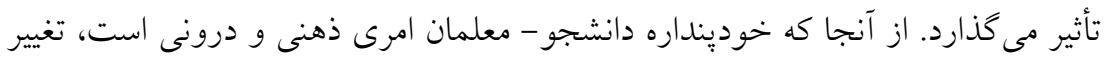

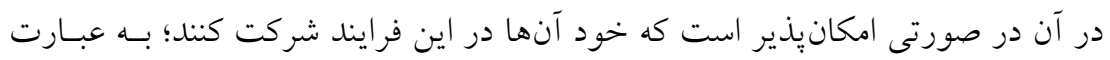

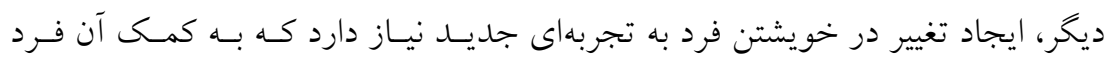

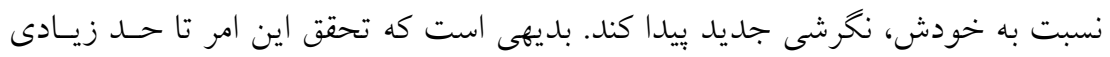

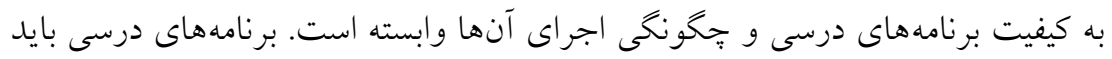

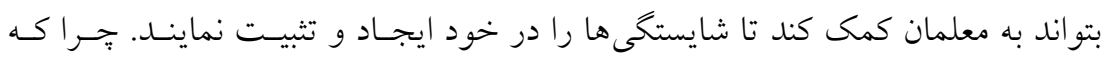

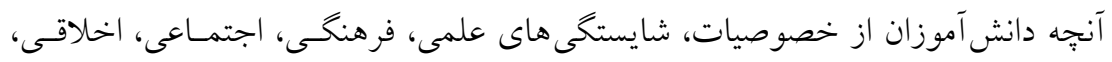

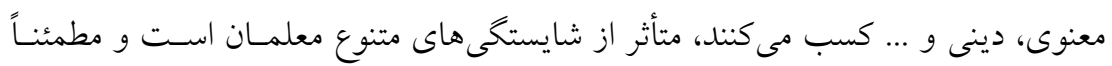

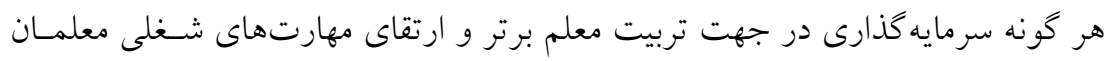

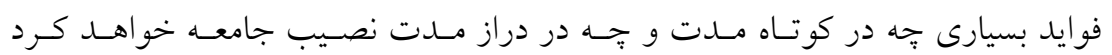

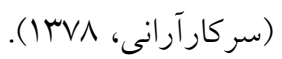

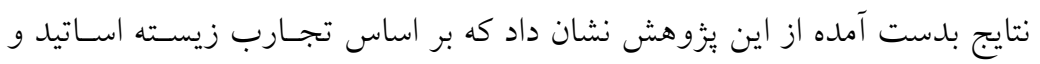

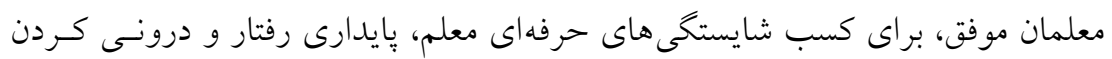

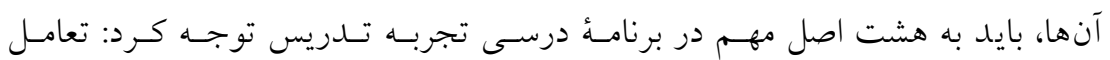

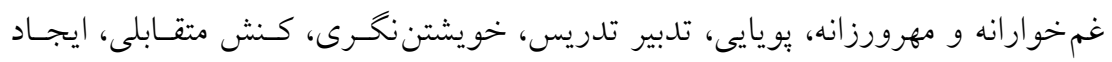

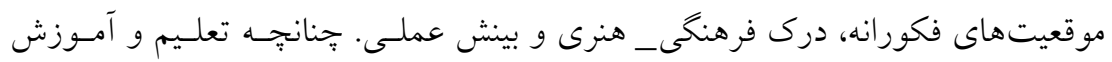

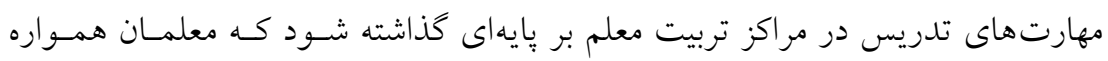

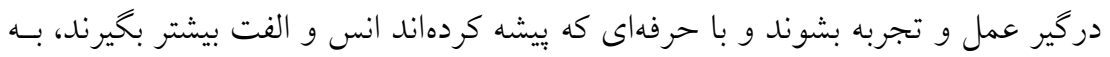


لياقت هاى فردى خود يى مى برند و آنها را باور مى سازند. دركيرى مستقيم با شيوههاى

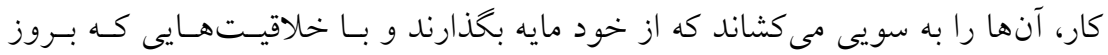

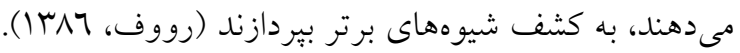

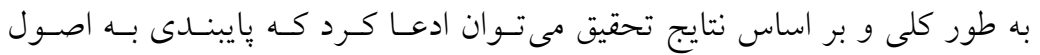

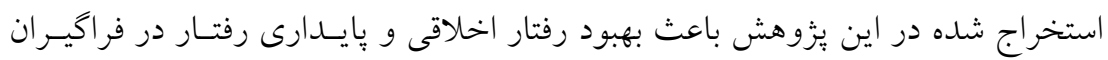

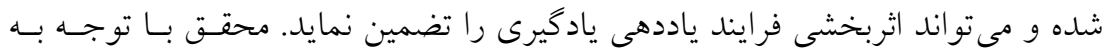

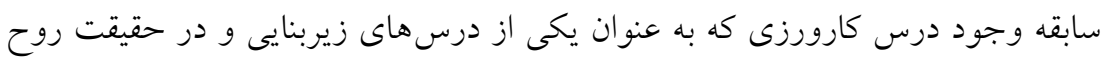

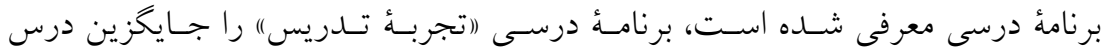

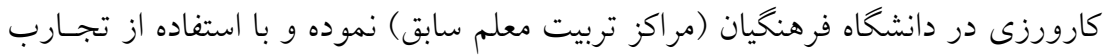

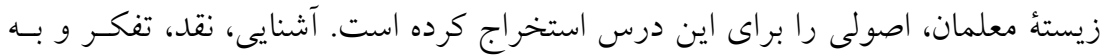

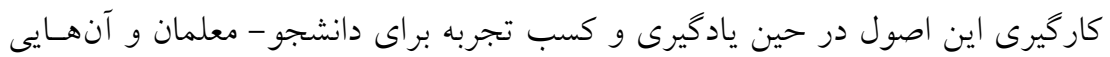

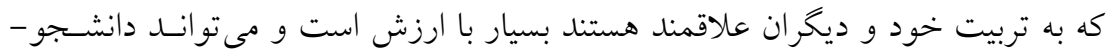

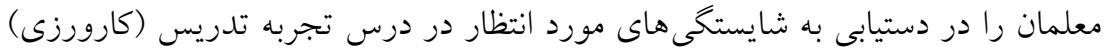

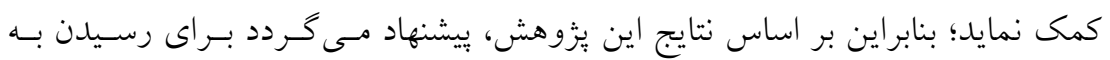

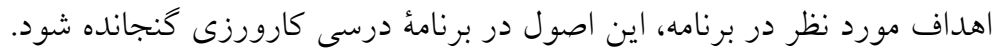

منابع

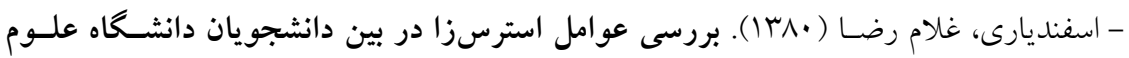

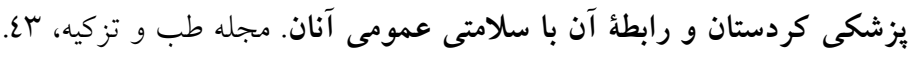

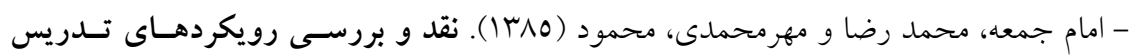

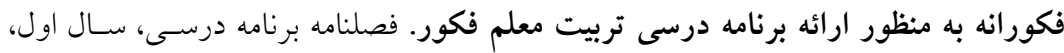

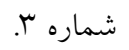

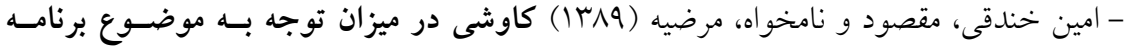

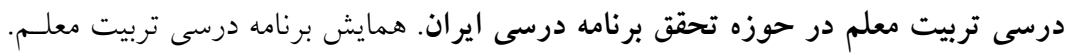
تهران دانشگاه شهيد رجايى.

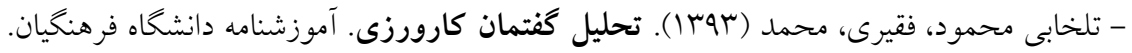
شماره 0، صص rا-1 
تبيين يديدارشناسانهُ اصول برنامهُ درسى ("تجربه تدريس)...

- جواهر فروشزاده، عبدالرحيم (1٪11) طرحى براى بهبود نظام تربيت معلـم ايـران اسـلامى.

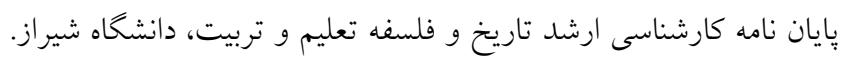

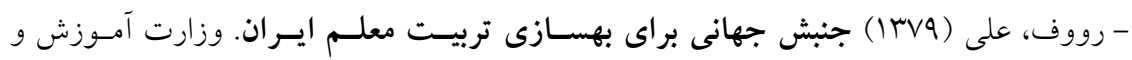

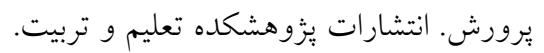

- رووف، على (1) (1). تربيت معلم و كارورزى. ويراست دوم. تهران، نشر روان.

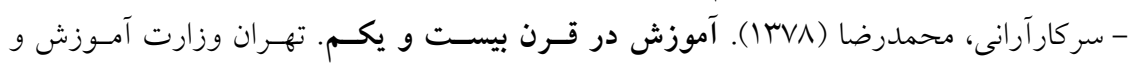

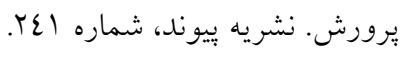

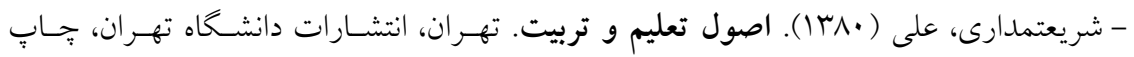
بانزدهم.

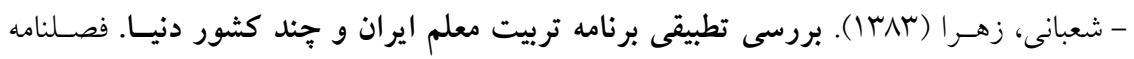

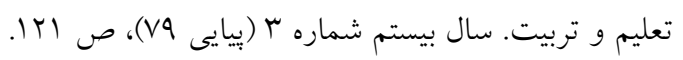

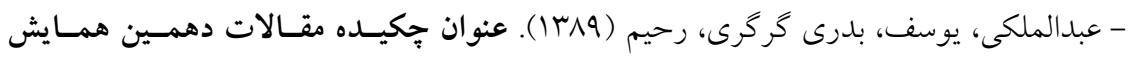
انجمن مطالعات برنامه درسى ايران دانشخاه شهيد رجايى. بورئ.

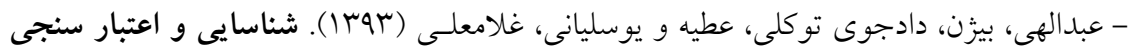

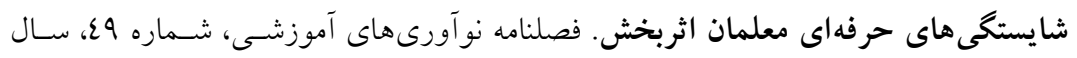
سيزدهم.

- عقيلى، عليرضا (TMT) (IT). صلاحيتهاى معلم در برنامه درسى تربيت معلم: شناسـايى، ميسزان تحقق و نقاط قوت و ضعف، از منظر اساتيد، دانشجويان و فارغ التحصيلان يايـان نامسه كارشناسى ارشد برنامه ريزى درسى، دانشخاه فردوسى مشـهـ، دانشـكده علـوم تربيتسى و روانشناسى.

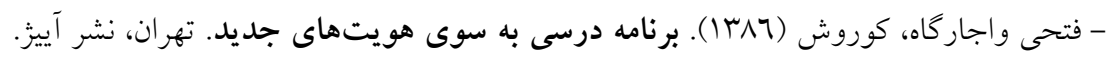

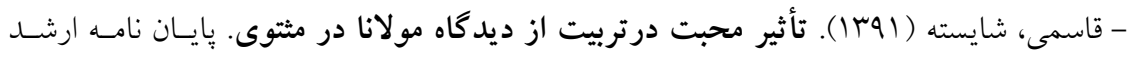
دانشخاه آزاد واحد خوراسگان. دانشكده علوم تربيتى و روانشناسى.

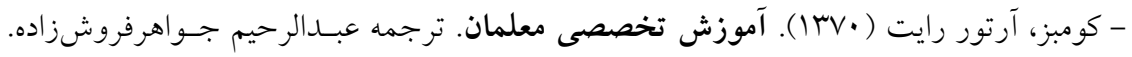
تهر ان: انتشارات رشد. - مشفق آرانى، بهمن (I IVNN). راهنماى تمرين معلمى. تهران انتشارات مدرسه. جّابٍ اول.

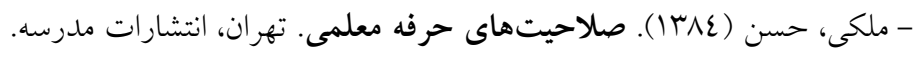

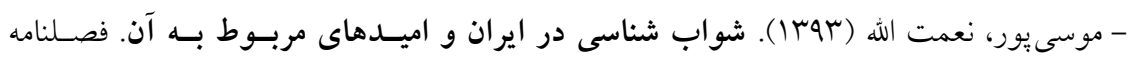
مطالعات برنامه درسى. سال هشتم. شماره بr. 


$$
\begin{aligned}
& \text { دو فصلنامه نظريه و عمل در برنامة درسى، شماره 7، سال سوم، ياييز و زمستان عوبا } \\
& \text { - مهرمحمدى، محمود (IMV9) جنبش جهانى براى بهسازى تربيت معلـم. يزوهشـكده تعلـيم و } \\
& \text { تربيت. متون علمى - بيزوهشى } 0 .
\end{aligned}
$$

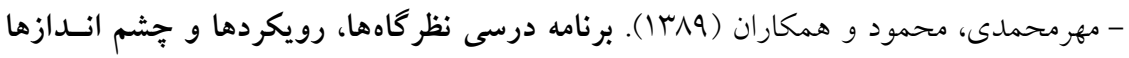

$$
\begin{aligned}
& \text { (ويراست دوم). تهران، انتشارات سمت ومترك. }
\end{aligned}
$$

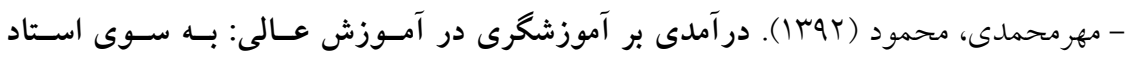

$$
\begin{aligned}
& \text { آموزش يزوه. تهران: دانشخاه تربيت مدرس، مركز نشر آثار علمى. }
\end{aligned}
$$

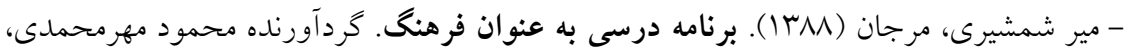

$$
\begin{aligned}
& \text { برنامه درسى نظر گاهها، رويكردها و جشم اندازها (ويراست دوم). تهران، انتشارات سمت. }
\end{aligned}
$$

- Bukaliya, R. (2012). The potential benefits and challenges of internship programs in an ODL institution: a case for the Zimbabwe open university. International journal on new trends in education and their implications, $3(1), 118-133$

- Dewey, Jone. (1933). How we Think: A Restatement of the Reflective.Thinking to the Educational Process. Boston: D.C. Heath and co.

- Eisner, Elliot. W. (1994). The Education Imagination: on the Design and Evaluation of School Programs. Third Edition. New York: MacMillan Publishing Company.

- Kouwenhoven, Wim. (2014). Relevant Curriculum Design and Development in Higher Education

- Milner, H. Richard. (2010). culture, curriculum, and identity in education.USA: Palgrave Macmillan.

- Pinar, W.F. (2004). Understanding curriculum. (with William, M, Reynolds, Slattery P, Tubman PM). Vol 17, New York: Peter Lang Publishing.

- Schon, Donald. A. (1993). The Reflective Practitioner: How Professionals Think. New York: Basic Books.

- Sergiovanni, A. (1991). The Principal Ship: A Reflective Practice Perspective. New York: Basic Books.

- Van Manen.Max. (1990). Researching lived experience: human science for an action sensitive pedagogy. NewYork: State University of New York Press. 